\title{
Caddo Sites on Patroon, Palo Gaucho, and Housen Bayous in Sabine County in the Sabine River Basin of East Texas
}

Timothy K. Perttula Heritage Research Center, Stephen F. Austin State University

Follow this and additional works at: https://scholarworks.sfasu.edu/ita

Part of the American Material Culture Commons, Archaeological Anthropology Commons, Environmental Studies Commons, Other American Studies Commons, Other Arts and Humanities Commons, Other History of Art, Architecture, and Archaeology Commons, and the United States History Commons

Tell us how this article helped you.

This Article is brought to you for free and open access by the Center for Regional Heritage Research at SFA ScholarWorks. It has been accepted for inclusion in Index of Texas Archaeology: Open Access Gray Literature from the Lone Star State by an authorized editor of SFA ScholarWorks. For more information, please contact cdsscholarworks@sfasu.edu. 


\section{Caddo Sites on Patroon, Palo Gaucho, and Housen Bayous in Sabine County in the Sabine River Basin of East Texas \\ Creative Commons License \\ (c) (1) (8)}

This work is licensed under a Creative Commons Attribution-NonCommercial 4.0 International License 


\title{
Caddo Sites on Patroon, Palo Gaucho, and Housen Bayous in Sabine County in the Sabine River Basin of East Texas
}

\author{
Timothy K. Perttula
}

\section{INTRODUCTION}

The 13 ancestral Caddo sites and collections discussed in this article were recorded by G. E. Arnold of The University of Texas at Austin between January and April 1940 as part of a WPA-funded archaeological survey of East Texas. The sites are located along the lower reaches of Patroon, Palo Gaucho, and Housen bayous in Sabine County, Texas (Figure 1). These bayous are eastward-flowing tributaries to the Sabine River in the Toledo Bend Reservoir area, but only 41SB30 is located below the current Toledo Bend Reservoir flood pool. This is an area where the temporal, spatial, and social character of the Caddo archaeological record is not well known, despite the archaeological investigations of Caddo sites at Toledo Bend Reservoir in the

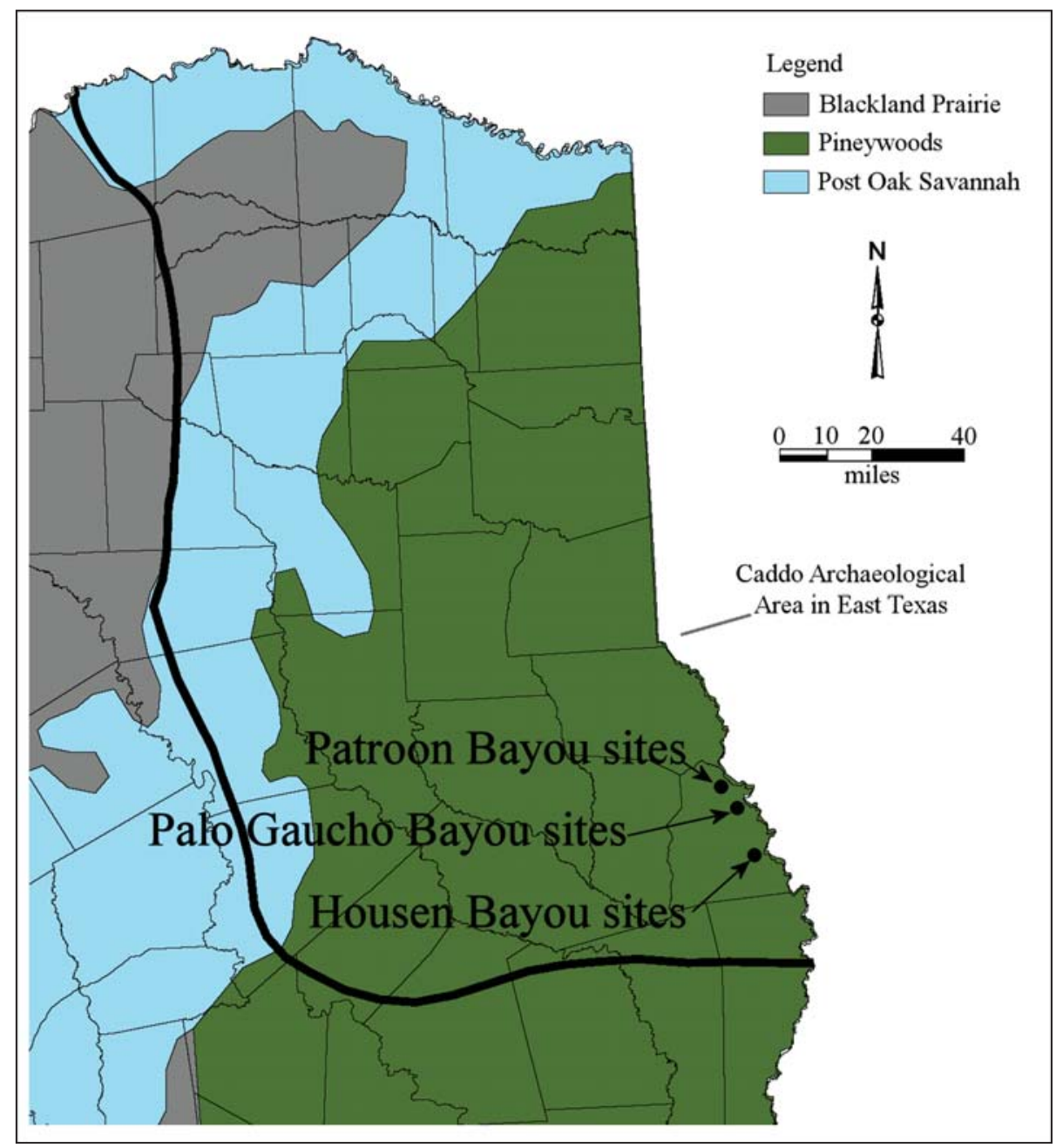

Figure 1. Location of Caddo sites on Patroon, Palo Gaucho, and Housen Bayous in East Texas. 
1960s-early 1970s, and in more recent years (Benham et al. 1973; Jensen 1968a, 1968b; Kelley 2006; Kelley et al. 2010; McClurkan et al. 1966; Robinson 1997; Scurlock 1964; Scurlock and Davis 1962; Woodall 1969).

\section{PATROON BAYOU SITES}

The Patroon Bayou Caddo sites are the northernmost cluster of sites (see Figure 1). The sites are situated either on alluvial terraces or on natural sandy rises in the floodplain, each covering between 0.5-1.0 acres, but 41SB10 is on the edge of an upland landform overlooking the floodplain of Patroon Bayou.

\section{SB9}

The small TARL artifact collection from 41SB9 includes one dart point and six sherds from Caddo ceramic vessels. The dart is a Woodland period Godley point made from a local yellow chert. Five of the six sherds (83 percent) are from grog-tempered vessels, including three plain body sherds, a parallel brushed body sherd with overlying parallel incised lines, and a sherd with opposed brushing marks that are divided by a vertical row of tool punctations (Figure 2a). The one sherd from a bone-tempered vessel has parallel brushing marks.

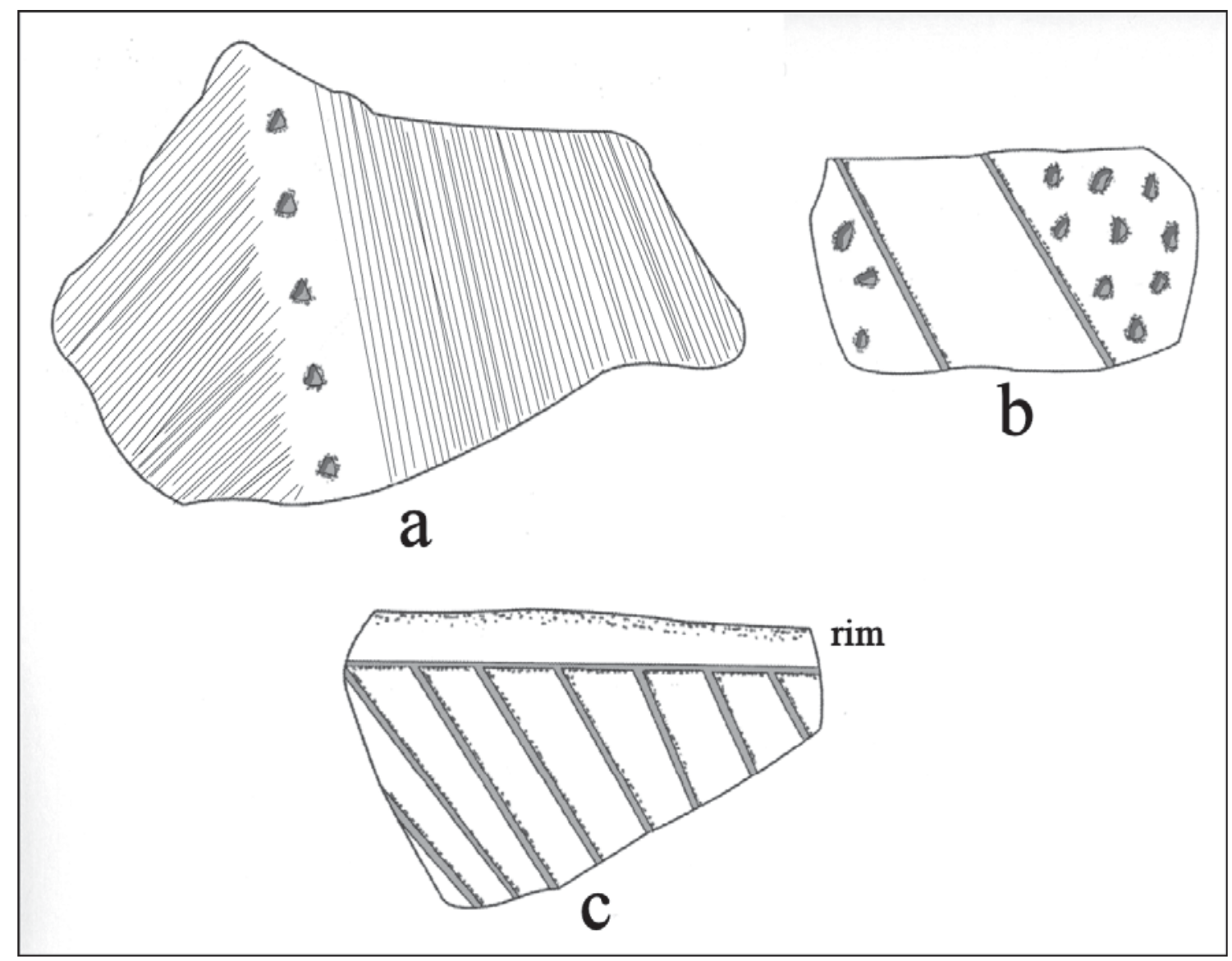

Figure 2. Selected decorative elements in utility ware sherds from Patroon Bayou sites: a, brushedpunctated, 41SB9; b, incised-punctated, 41SB11; c, incised rim, 41SB12. 


\section{SB10}

The Caddo ceramic assemblage from 41SB 10 includes 10 sherds, 60 percent from grog-tempered vessels and 40 percent from bone-tempered vessels. Among the grog-tempered sherds are four plain body sherds, a rim with vertical brushing marks, and a body sherd with parallel rows of incised lines adjacent to a row of tool punctations. Three of the bone-tempered sherds have either parallel or vertical brushing marks, and the other is a spindle whorl made from a base sherd. The spindle whorl is $76 \mathrm{~mm}$ in diameter, and the drilled perforation is $15.2 \mathrm{~mm}$ in diameter.

\section{SB11}

Most of the 60 Caddo ceramic sherds from 41SB11 are from grog-tempered vessels (87 percent); the remainder are from bone-tempered vessels. Eighteen sherds are from decorated portions of vessels; the plain to decorated sherd ratio is 2.33. Many of the decorated sherds have incised decorative elements (44 percent), along with sherds with brushed (22 percent), incised-punctated (17 percent), and engraved (17 percent) decorations.

The grog-tempered incised sherds have either parallel or straight lines, while the grog-tempered sherds with engraved decorations have only parallel and opposed lines. Grog-tempered brushed sherds are body sherds with parallel brushing marks. Two of the grog-tempered incised-punctated sherds have straight or diagonal lines adjacent to a row of tool punctations (probably at the rim-body juncture), while the third has incised triangles filled with tool punctations as well as diagonal incised panels (see Figure $2 \mathrm{~b}$ ). The bonetempered sherds include one body sherd with parallel engraved lines, one body sherd with parallel brushing marks, and a body sherd with parallel incised lines.

\section{$41 S B 12$}

There are 47 Caddo sherds in the 41SB12 assemblage, 83 percent from grog-tempered vessels and 17 percent from bone-tempered vessels. Approximately 70 percent of the assemblage are plain rim and body sherds, and 14 sherds have decorations.

The decorated sherds from bone-tempered vessels include one parallel brushed body sherd, a rim sherd with a horizontal incised line below the lip and rows of cane punctations on the rim itself, one body sherd with parallel incised lines, and a Dunkin Incised rim with diagonal incised lines (see Suhm and Jelks 1962:Plate 19h).

Ten of the grog-tempered sherds from 41SB12 have decorative elements. This includes four body sherds with parallel incised lines, another with curvilinear incised lines, and a rim from a Dunkin Incised vessel with a horizontal incised line under the lip and diagonal incised lines on the rim itself (see Figure 2c). Two other body sherds have rows of fingernail punctations, a rim sherd has rows of tool punctations below a single horizontal incised line, and a body sherd has vertical engraved panels that are either plain or have diagonal lines.

\section{PALO GAUCHO BAYOU SITES}

The middle cluster of Caddo sites are on Palo Gaucho Bayou (see Figure 1), or along tributaries such as Boregas and Carassee creeks near their confluence with the bayou. The Caddo sites are on alluvial terrace landforms or a low sandy rise in the floodplain, and cover between $0.5-1.0$ acres in size. 


\section{SB22}

Arnold (1940) collected 11 sherds from Caddo vessels from 41SB22. About 82 percent of the sherds are from grog-tempered vessels; the remaining 18 percent are from bone-tempered vessels. None of the bone-tempered sherds have decorative elements, but two of the grog-tempered sherds do: a body sherd with parallel brushing marks, and a possible Dunkin Incised body sherd with horizontal and diagonal incised lines on the lower rim and irregular rows of tool punctations on at least the upper vessel body.

\section{$41 S B 23$}

There are 83 sherds from Caddo ceramic vessels at this site, as well as a single piece of daub/burned clay. The sherds are from grog-tempered (58 percent), bone-tempered (41 percent) and shell-tempered (1 percent) vessels; the one shell-tempered sherd is a plain body sherd.

About 41 percent of the sherds from 41SB23 are from vessels with decorations, including 35 percent of the bone-tempered sherds and 46 percent of the grog-tempered sherds. The most common decorative method in the assemblage is incised ( 38 percent of the decorated sherds), followed by punctated ( 29 percent), and brushed (21 percent (Table 1). There are no fine ware sherds in the assemblage.

Table 1. Decorated sherds from 41SB23.

Decorative method/

Decorative element

Grog Bone

$\mathrm{N}$

\section{Brushed}

parallel brushing marks

vertical brushing marks

\section{Brushed-Incised}

vertical brushed and vertical-curvilinear

incised lines

\section{Incised}

curvilinear lines

diagonal opposed lines

horizontal lines

parallel lines

vertical lines

vertical panels filled with diagonal

incised lines

\section{Incised-Punctated}

incised triangles filled with tool punctates

\section{Punctated}

circular punctated rows

fingernail punctated rows

opposed fingernail punctated rows

tool punctated rows

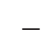

7

$-$

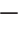

1

4

1

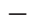

1

7

1 
Table 1. Decorated sherds from 41SB23, cont.

Decorative method/

Decorative element

Grog

Bone

$\mathrm{N}$

Ridged

parallel ridges

1

$-$

1

Totals

22

12

34

The one brushed-incised sherd from 41SB23 has vertical brushing marks on either side of a set of curvilinear incised lines and a single vertical incised line (Figure 3a). A grog-tempered rim sherd has curvilinear incised lines (Figure 3b), while a bone-tempered body sherd is from a Pease Brushed-Incised jar with diagonal hatched vertical incised panels (Figure 3c). Incised-punctated sherds from the site have incised triangles along the rim that are filled with rows of tool punctations.

The punctated sherds from 41SB23 primarily have horizontal rows of fingernail punctations (70 percent of the punctated sherds), and one body sherd has opposed rows of fingernail punctations (see Table 1). There are also sherds with circular and tool punctated rows on vessel rims.

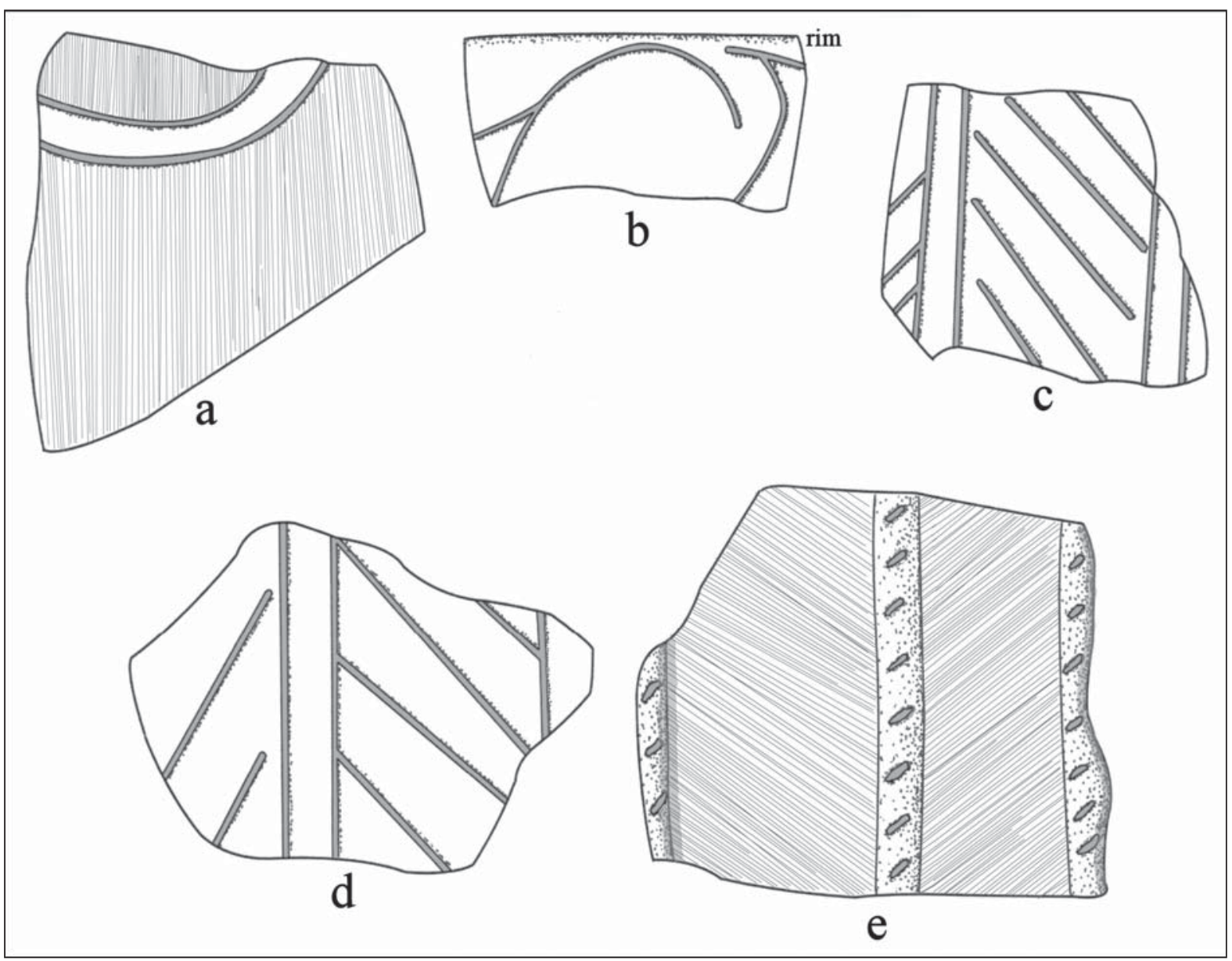

Figure 3. Utility ware sherd decorative elements from Palo Gaucho Bayou sites: a-c, 41SB23; d-e, 41SB28. 
This site also has a grog-tempered Belcher Ridged, var. Belcher body sherd (e.g., Girard 2007:15). This is a post-A.D. 1500 utility ware in parts of the mid-Sabine River basin and along the Red River in Northwest Louisiana (Kelley 2006:55).

\section{SB28}

The Texas Archeological Research Laboratory at The University of Texas at Austin (TARL) collection from 41SB28 includes two projectile points and 444 sherds from ceramic vessels. The projectile points are a grayish-brown Bonham arrow point and a Late Archaic Williams dart point made from a brown chert.

The ceramic sherds include 297 plain rim, body, and base sherds and 148 decorated rim and body sherds. The plain to decorated sherd ratio is 2.0. About 91 percent of the sherds are from grog-tempered vessels, with the remainder from bone-tempered vessels.

The decorated sherds from 41SB28 are dominated by utility wares (Table 2), particularly sherds from incised ( $n=95,65$ percent of the sherds from utility ware vessels) and incised-punctated ( $n=32,22$ percent) vessels; sherds from punctated vessels comprise 13 percent of the utility wares. Only 0.7 percent of the decorated sherds are from fine ware vessels. This sherd, from a bone-tempered vessel, has a narrow crosshatched engraved zone.

Table 2. Decorated sherds from utility ware vessels at 41SB28.

Decorative method/

Decorative element

Grog

Bone

$\mathrm{N}$

\section{Brushed-Appliqued}

vertical appliqued fillets and opposed

brushing marks

\section{Incised}

cross-hatched lines

diagonal lines

diagonal lines, L-R

diagonal opposed lines

diagonal opposed and vertical lines

horizontal lines

horizontal and diagonal opposed lines

opposed lines

parallel lines

straight line

1
2
1
11
1
4
1
8
49

Incised-Punctated

diagonal lines (L-R) and tool punctated

1

$\begin{array}{ll}- & 11\end{array}$

$\begin{array}{ll}- & 1\end{array}$

$\begin{array}{ll}- & 4\end{array}$

$\begin{array}{ll}- & 1\end{array}$

119

5

$2+11$

punctations 
Table 2. Decorated sherds from utility ware vessels at 41SB28, cont.

\begin{tabular}{|c|c|c|c|}
\hline $\begin{array}{l}\text { Decorative method/ } \\
\text { Decorative element }\end{array}$ & Grog & Bone & $\mathrm{N}$ \\
\hline $\begin{array}{l}\text { horizontal and curvilinear lines and } \\
\text { curvilinear zone filled with circular } \\
\text { punctations }\end{array}$ & 1 & - & 1 \\
\hline $\begin{array}{l}\text { horizontal and diagonal lines (R-L) and } \\
\text { diagonal panels filled with tool punctates }\end{array}$ & 3 & - & 3 \\
\hline $\begin{array}{l}\text { horizontal and diagonal opposed lines, } \\
\text { incised pendant triangle filled with } \\
\text { punctates and a large tool-punctated } \\
\text { filled triangle }\end{array}$ & 1 & - & 1 \\
\hline $\begin{array}{l}\text { horizontal and diagonal opposed lines, } \\
\text { diagonal opposed punctated row, and } \\
\text { triangle zone filled with tool punctates }\end{array}$ & 1 & - & 1 \\
\hline $\begin{array}{l}\text { incised triangles filled with tool } \\
\text { punctations }\end{array}$ & 3 & - & 3 \\
\hline $\begin{array}{l}\text { opposed lines and row of linear tool } \\
\text { punctations }\end{array}$ & 1 & - & 1 \\
\hline $\begin{array}{l}\text { parallel lines and adjacent tool } \\
\text { punctated zone }\end{array}$ & 1 & - & 1 \\
\hline $\begin{array}{l}\text { straight incised line and adjacent circular } \\
\text { punctated zone }\end{array}$ & 3 & - & 3 \\
\hline $\begin{array}{l}\text { straight line and adjacent tool punctated } \\
\text { zone }\end{array}$ & 11 & 1 & 12 \\
\hline $\begin{array}{l}\text { vertical lines and vertical panel filled } \\
\text { with tool punctations }\end{array}$ & 1 & - & 1 \\
\hline
\end{tabular}

\section{Punctated}

small circular punctated rows

circular punctated rows

fingernail punctated rows

linear tool punctated row

tool punctated rows

$\begin{array}{rrr}1 & - & 1 \\ 1 & - & 1 \\ 1 & 4 & 5 \\ 1 & - & 1 \\ 11 & - & 11 \\ 134 & 13 & 147\end{array}$

Totals

L-R=left-right; incised line begins at the left at the rim and ends at the right at the bottom of the rim; R-L=right to left; incised line begins at the right at the rim and ends at the left at the bottom of the rim

Only one sherd from 41SB28 is from a vessel with brushing marks. This is a body sherd from a Pease Brushed-Incised vessel with appliqued panels filled with brushing (see Figure 3e). Another Pease BrushedIncised vessel has vertical incised panels filled with diagonal opposed incised lines (see Figure 3d).

Incised sherds are primarily from Dunkin Incised vessels with diagonal and diagonal opposed incised lines on the rim panel (Figure 4d). Other rim sherds have sets of horizontal incised lines, and are probably from Davis Incised jars (see Suhm and Jelks 1962:Plate 18). 


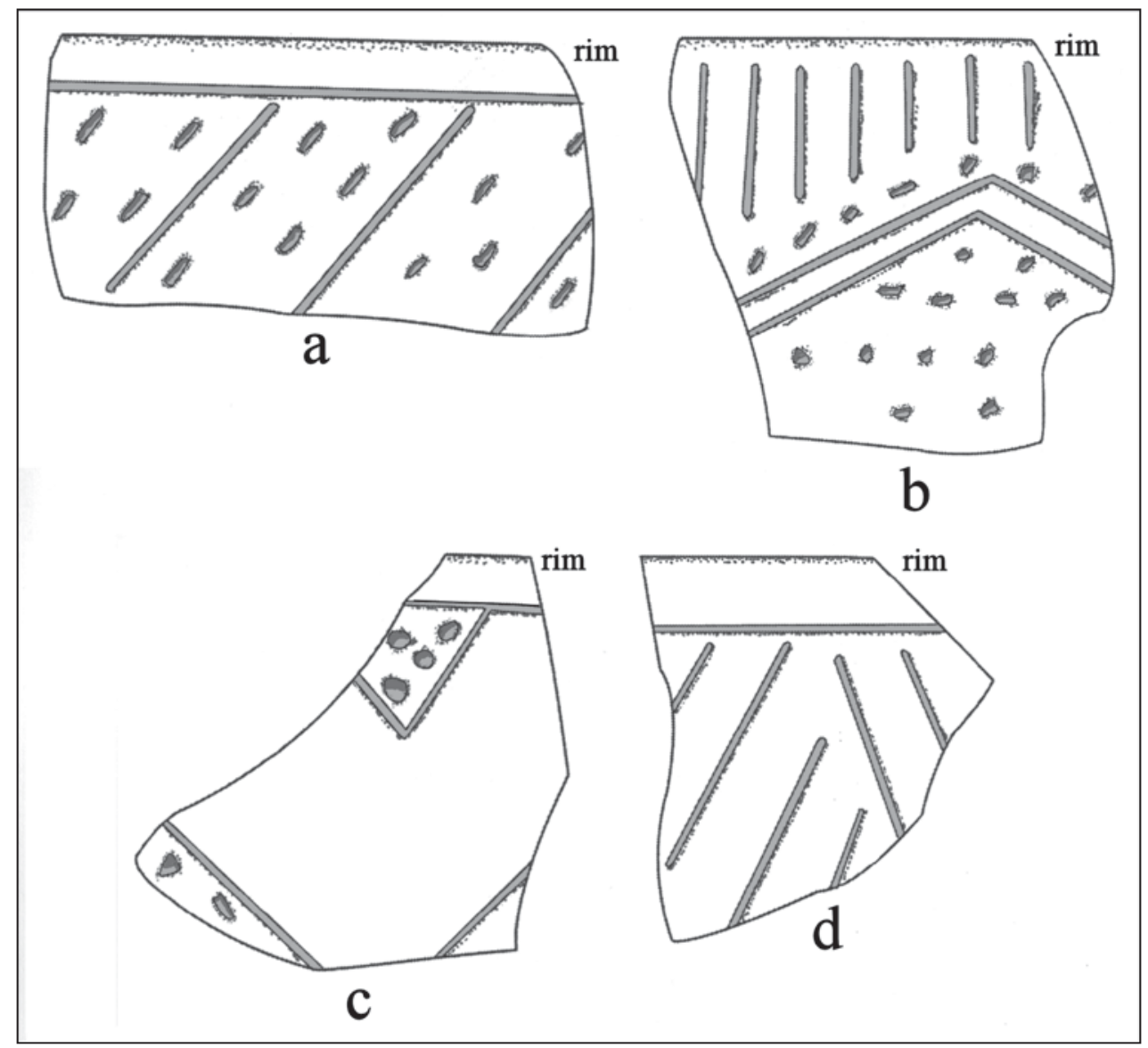

Figure 4. Utility ware sherd decorative elements from 41SB28 on Palo Gaucho Bayou sites: a-c, incised-punctated rim sherds; d, incised rim sherd.

The sherds from incised-punctated vessels at 41SB28 have particularly diverse decorative elements (see Figure 4a-c and Table 2), and many may be from Pennington Punctated-Incised vessels, including bowls and carinated bowls (see Suhm and Jelks 1962:Plate 61). These sherds have rows of incised triangles filled with punctations; diagonal incised panels filled with punctations (see Figure 4a); vertical incised panels filled with punctations or left plain; curvilinear incised zones filled with punctations; horizontal and diagonal incised lines with small incised pendant triangles and large incised triangles filled with circular punctations (see Figure 4c); and sets of vertical and diagonal opposed incised lines divided by a row of diagonal opposed tool punctations, and below that a triangular zone filled with tool punctations (see Figure 4b).

\section{SB29}

The TARL collection from this Palo Gaucho Bayou site has two Woodland period dart points (Gary and Kent types) of local red or brown chert, a clay coil fragment, one piece of burned clay, and 298 ceramic sherds. One of the ceramic sherds is from a Woodland period Marksville Stamped grogtempered vessel, and the other 297 sherds are from ancestral Caddo wares. The Marksville Stamped, var. unspecified sherd, probably from a vessel dating from ca. A.D. 100-300 (Brown 1998), has broad U-shaped horizontal and curvilinear incised lines with one curvilinear zone filled with rows of small circular stamped impressions (Figure 5). A vessel with similar incised-stamped decorative elements was recovered from a Woodland period burial feature at the Coral Snake Mound site at Toledo Bend Reservoir (Jensen 1968a:Figures 8-9). 


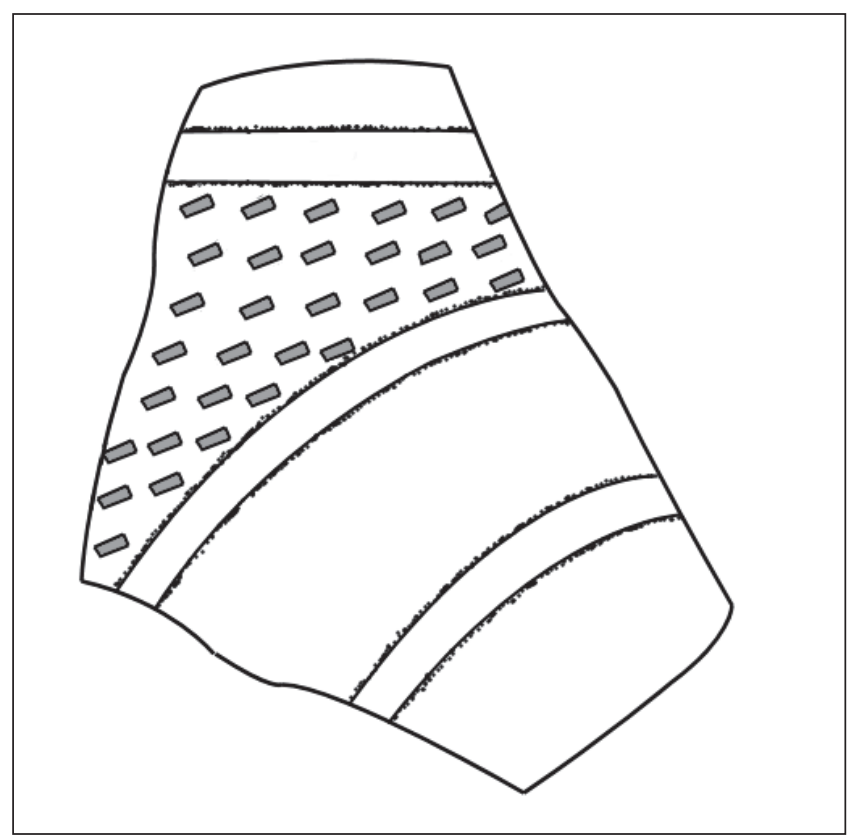

Figure 5. Marksville Stamped body sherd from 41SB29.

About 58 percent of the Caddo sherds are from vessels tempered with grog; the remaining 42 percent are from bone-tempered vessels. The Caddo ceramic vessel sherds include 274 with different kinds of decorative elements, with only 7.0 percent from fine wares, however.

The fine ware sherds have concentric semi-circle, cross-hatched zone, hatched zone and hatched vertical panels, as well as hatched pendant triangle elements, and also a variety of sherds with horizontal and diagonal, curvilinear, and vertical engraved lines (Table 3 and Figure 6a). One bone-tempered rim has a horizontal line below the rim and a central circle element (Figure 6c); this circle has an inner engraved diamond, as commonly seen on some varieties of Ripley Engraved, and vessels with these decorative elements have been found in burials at sites at Toledo Bend Reservoir (McClurkan et al. 1966; Woodall 1969) as well as sites in the uplands east of the Sabine River (Kelley 2006:61).

Table 3. Selected decorative elements on decorated sherds from fine ware vessels at 41SB29.

Decorative method/

Decorative element

Grog

Bone

$\mathrm{N}$

\section{Engraved}

concentric semi-circles

cross-hatched zone

$\begin{array}{lll}- & & 1\end{array}$

diagonal opposed lines

$\begin{array}{ll}- & 1\end{array}$

1

curvilinear hatched zone

1

narrow hatched zone

1

hatched pendant triangle

hatched vertical panel

$\begin{array}{cc}- & 1 \\ - & 1 \\ 1 & 1 \\ - & 1\end{array}$


Table 3. Selected decorative elements on decorated sherds from fine ware vessels at 41SB29, cont.

Decorative method/

Decorative element

Grog Bone N

horizontal and diagonal lines

horizontal lines, and circle element

$-\quad 1$

1

with inner central diamond

horizontal line and excised pendant

triangles

horizontal and curvilinear lines and

hatched zone

horizontal and vertical lines and

curvilinear element

opposed lines

parallel lines

rectilinear lines

straight line

1

1

1

$\begin{array}{llll}- & & 1\end{array}$

$\begin{array}{lll}1 & 1\end{array}$

$\begin{array}{lll}1 & 1\end{array}$

Totals

11
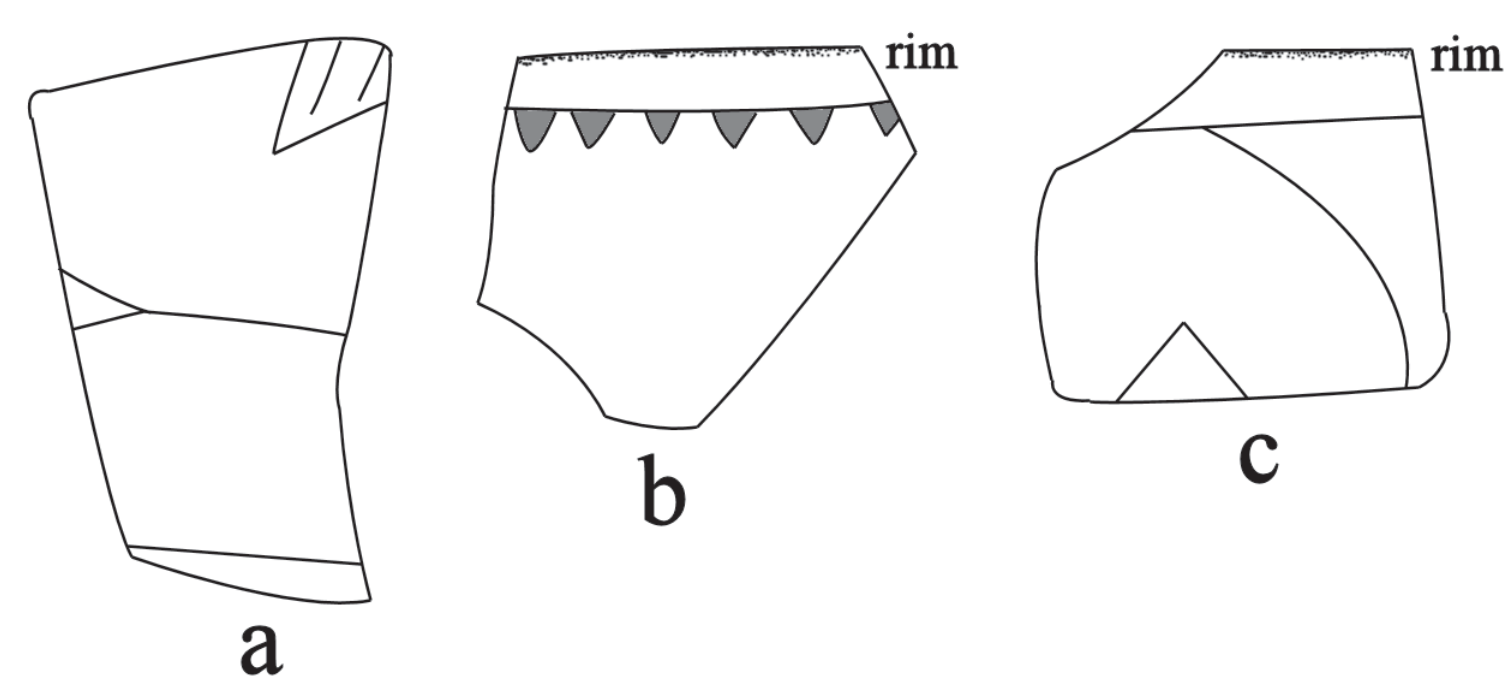

$\begin{array}{lll}- & 1 & 1\end{array}$

$\begin{array}{lll}4 & - & 4\end{array}$

$\begin{array}{lll}1 & - & 1\end{array}$

$\begin{array}{lll}1 & - & 1\end{array}$

8

19

Figure 6. Selected engraved decorative elements in the fine ware sherds from 41SB29.

Another engraved rim has a row of excised pendant triangles on a single horizontal engraved line below the vessel lip (see Figure 6b). This rim may be from a Patton Engraved vessel, an Historic Caddo ceramic type in the Neches-Angelina river basins in East Texas, or a completely unrelated fine ware local to the mid- to lower Sabine River basin.

About 44 percent of the sherds from utility ware vessels have incised decorative elements (Table 4). Another 40 percent of the sherds are from utility ware vessels with brushing marks, 7.8 percent are sherds from incised-punctated vessels, and 4.3 percent are sherds from vessels with brushed-incised decorative elements. Overall, a considerable portion (44 percent) of the utility ware sherds from 41SB29 are from 
vessels that are decorated with brushing marks on the rim and/or the vessel body, suggesting a Late Caddo period occupation at the site.

Table 4. Selected decorative elements on decorated sherds from utility ware vessels at 41SB29.

Decorative method/

Decorative element

Grog

Bone

$\mathrm{N}$

\section{Brushed}

diagonal brushing

horizontal brushing

opposed brushing

parallel brushing marks

4

\section{Brushed-Incised}

opposed brushed with overlying straight incised lines

parallel brushed-incised

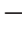

4

$\begin{array}{rrr}1 & - & 1 \\ 1 & 1 & 2 \\ 3 & 1 & 4 \\ 42 & 52 & 94\end{array}$

\section{Incised}

curvilinear lines

diagonal lines, L-R

diagonal lines, R-L

diagonal opposed lines

horizontal lines

horizontal and diagonal lines, R-L

horizontal and diagonal lines

opposed lines

parallel lines

straight line

vertical and diagonal lines

\section{Incised-Appliqued}

diagonal opposed lines divided by vertical appliqued fillet

\section{Incised-Punctated}

band incised zone with tool punctates curvilinear incised lines and adjacent tool punctated zone

curvilinear incised line and curvilinear tool punctated rows

diagonal incised lines and vertical tool punctated rows diagonal incised lines-tool punctated rowand horizontal incised lines diagonal and vertical lines and vertical row of tool punctates

$$
5
$$

1

1

3

2

1

4

$$
1
$$

40

6

\section{1}

\section{-}

\section{1}

1

1

4


Table 4. Selected decorative elements on decorated sherds from utility ware vessels at 41SB29, cont.

\begin{tabular}{|c|c|c|c|}
\hline $\begin{array}{l}\text { Decorative method/ } \\
\text { Decorative element }\end{array}$ & Grog & Bone & $\mathrm{N}$ \\
\hline $\begin{array}{l}\text { diagonal opposed lines and vertical row } \\
\text { of tool punctates }\end{array}$ & 1 & - & 1 \\
\hline $\begin{array}{l}\text { diagonal opposed lines and tool punctates } \\
\text { at rim-body juncture }\end{array}$ & 1 & - & 1 \\
\hline $\begin{array}{l}\text { horizontal-diagonal lines and triangle } \\
\text { filled with tool punctates }\end{array}$ & - & 1 & 1 \\
\hline $\begin{array}{l}\text { horizontal and vertical lines and row of } \\
\text { tool punctates under horizontal lines }\end{array}$ & 1 & - & 1 \\
\hline incised triangle filled with tool punctates & 2 & - & 2 \\
\hline $\begin{array}{l}\text { parallel incised lines and adjacent tool } \\
\text { punctated zone }\end{array}$ & 4 & - & 4 \\
\hline $\begin{array}{l}\text { straight incised line and adjacent } \\
\text { tool punctated zone }\end{array}$ & 4 & - & 4 \\
\hline $\begin{array}{l}\text { Incised-Stamped } \\
\text { curvilinear lines and curvilinear stamped } \\
\text { rows }\end{array}$ & 1 & - & 1 \\
\hline $\begin{array}{l}\text { Pinched } \\
\text { parallel pinched ridges }\end{array}$ & 1 & - & 1 \\
\hline $\begin{array}{l}\text { Punctated } \\
\text { fingernail punctated rows } \\
\text { tool punctated rows }\end{array}$ & $\begin{array}{l}6 \\
1\end{array}$ & $\begin{array}{l}- \\
-\end{array}$ & $\begin{array}{l}6 \\
1\end{array}$ \\
\hline $\begin{array}{l}\text { Ridged } \\
\text { parallel ridged }\end{array}$ & 1 & - & 1 \\
\hline Totals & 145 & 110 & 255 \\
\hline
\end{tabular}

L-R=left-right; incised line begins at the left at the rim and ends at the right at the bottom of the rim; $\mathrm{R}-\mathrm{L}=$ right to left; incised line begins at the right at the rim and ends at the left at the bottom of the rim

The brushed sherds have diagonal or horizontal brushing marks on the rim, and probably vertical brushing marks on the vessel body (see Table 4). Most of the brushed-incised sherds are likely from the bodies of jars that have vertical brushing marks interspersed with vertical incised lines. The rim sherds with incised decorative elements have diagonal, horizontal and diagonal, diagonal opposed, and horizontal lines. One grog-tempered incised-appliqued body sherd is from a Pease Brushed-Incised jar with vertical appliqued fillets creating panels on the vessel body filled with diagonal opposed incised lines (Figure 7b).

The incised-punctated sherds also include several sherds from other Pease Brushed-Incised jars. These sherds have panels defined by vertical rows of tool punctations, and the panels are filled with diagonal or diagonal opposed incised lines (see Figure 7e-f). Other incised-punctated sherds are from jars with rows of incised triangles that are filled with rows of tool punctations (see Figure 7c-d). One of the incised-punctated sherds has a row of tool punctations at the rim-body juncture and diagonal opposed incised decorative elements on the rim itself (see Table 4). 


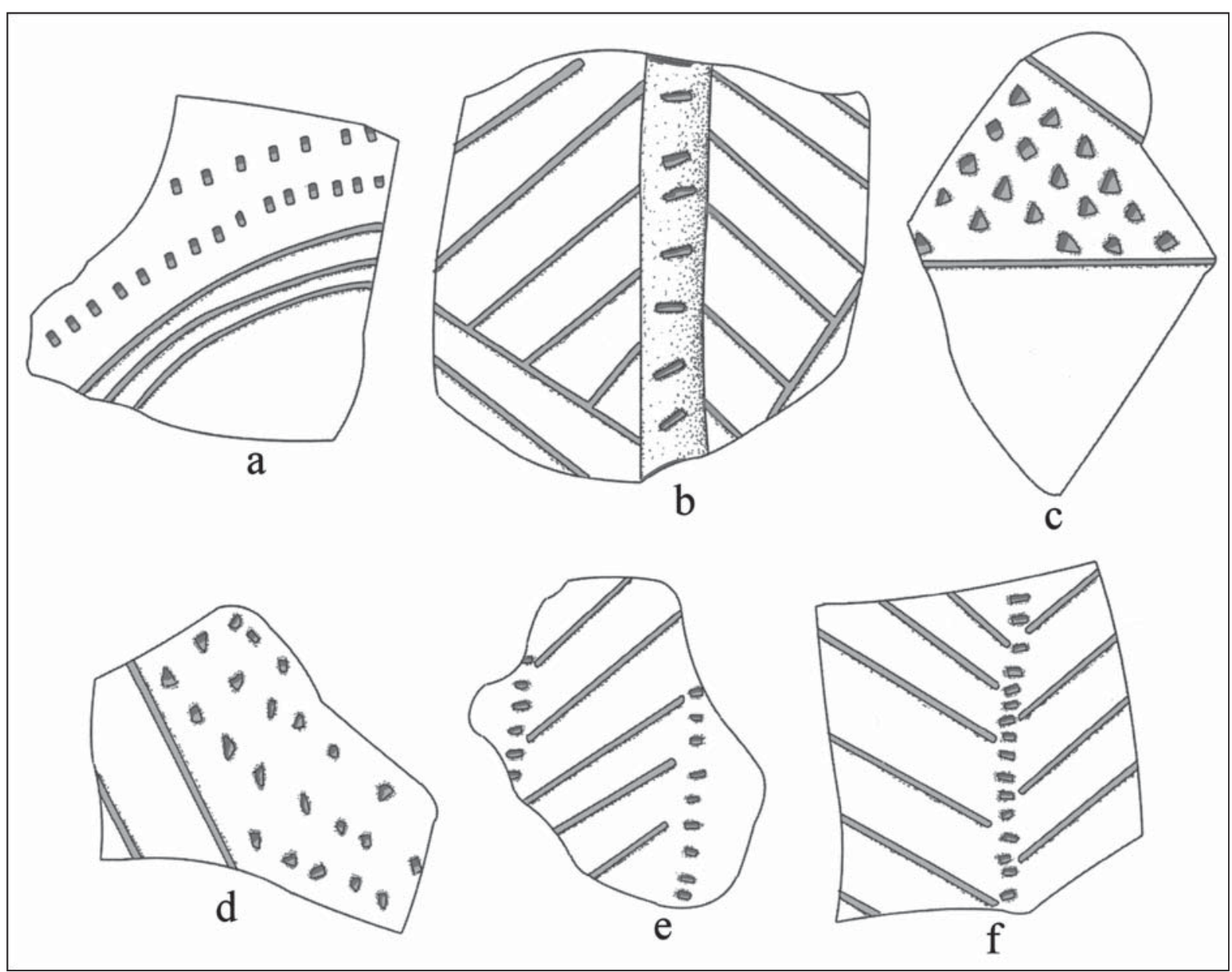

Figure 7. Selected decorative elements in the utility ware sherds from 41SB29: a, incised-stamped; $b$, incisedappliqued; c-f, incised-punctated.

One body sherd is from a Killough Pinched jar: it has parallel pinched ridges (see Table 4). The few punctated sherds have rows of either fingernail or tool punctations.

One grog-tempered sherd from 41SB29 may be from a post-A.D. 1500 Cowhide Stamped jar (see Figure 7a). It has a set of closely-spaced curvilinear incised lines and two rows of curvilinear dentate stamps (see Suhm and Jelks 1962:29). Another one of the utility ware sherds (0.4 percent) is from a Belcher Ridged, var. Belcher vessel, also likely manufactured after ca. A.D. 1500.

\section{SB30}

During the plowing of the site several years before Arnold's survey, one Caddo burial had been exposed here during plowing and then dug up by the landowner (Arnold 1940). Arnold collected 33 Caddo ceramic sherds from 41SB30, 52 percent of which are from bone-tempered vessels; 48 percent of the sherds are from grog-tempered vessels.

Nine of the sherds, all from utility ware vessels, have decorative elements. This includes six sherds (67 percent) with brushed decorations, among them a rim with horizontal brushing marks. Two sherds have parallel incised lines, and the final decorated sherd has diagonal incised lines (right to left) above a row of tool punctations at the rim-body juncture. 


\section{SB34}

This site may have had midden deposits or burials, because numerous bones (unidentified as to animal or human) had been exposed there during recent plowing (Arnold 1940). Both chipped stone tools and ceramic sherds were collected by Arnold from 41SB34.

The chipped stone tools include a possible Middle Archaic Morrill dart point made from a local brown chert, a Kent dart point fragment made of local red chert, and two end scrapers on non-local gray chert. Arnold also collected a Perdiz arrow point on a local reddish-yellow chert.

There are 175 decorated sherds in the TARL collections from 41SB34: 94.9 percent from utility ware vessels and 5.1 percent from fine ware vessels. Approximately 89 percent of these sherds are from grogtempered vessels and the remainder are from bone-tempered vessels.

About 49 percent of the utility ware vessel sherds have incised decorative elements (Table 5). Sherds from brushed vessels only comprise 18 percent of the utility wares, and sherds with brushing marks and other decorative methods (i.e., appliqued, incised, incised-appliqued, punctated, and punctated-incised) account for 6.9 percent of the utility ware assemblage. Sherds from incised-punctated vessels total 9.7 percent of the utility wares.

Table 5. Selected decorative elements on decorated sherds from utility ware vessels at 41SB34.

Decorative method/

Decorative element

Grog

Bone

$\mathrm{N}$

\section{Appliqued}

parallel appliqued ridges

straight appliqued fillet

straight appliqued ridge

1

1

\section{Brushed}

diagonal brushing marks

horizontal brushing marks

opposed brushing marks

overlapping brushing marks

parallel brushing marks

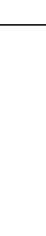

Bone

$\begin{array}{ll}- & 1 \\ - & 1 \\ - & 1\end{array}$

\section{Brushed-Appliqued}

diagonal brushed and straight

appliqued fillet

parallel brushed and parallel appliqued

ridges

\section{Brushed-Incised}

parallel brushed-incised

parallel brushed and overlying parallel

$\begin{array}{lr}- & 2 \\ - & 4 \\ - & 4 \\ - & 1 \\ 4 & 21\end{array}$

incised lines

$\begin{array}{lll}2 & 1 & 3 \\ 1 & - & 1\end{array}$


Table 5. Selected decorative elements on decorated sherds from utility ware vessels at 41SB34, cont.

Decorative method/

Decorative element

Grog Bone

$\mathrm{N}$

Brushed-Incised-Appliqued

parallel brushed-incised and parallel

appliqued fillets

\section{Brushed-Punctated}

parallel brushed and tool punctated

row through brushing

\section{Brushed-Punctated-Incised}

diagonal, vertical, and opposed

brushing, diagonal opposed incised

lines, and row of tool punctates

\section{Incised}

curvilinear lines

diagonal lines, L-R

diagonal opposed lines

horizontal lines

horizontal line under lip

horizontal-diagonal lines, L-R

horizontal-diagonal lines, R-L

horizontal-diagonal (R-L), and

curvilinear lines

horizontal lines and vertical panels

filled with diagonal lines

slanted scroll and cross-hatched

scroll fill zones

vertical panels filled with diagonal

opposed lines

opposed lines

parallel lines

straight line

vertical lines

vertical lines (in vessel body)

2

2
11

11

2

$-$

2

4

1

1

\section{Incised-Appliqued}

parallel and diagonal lines and straight

appliqued fillet

diagonal opposed lines and parallel

1

2

11

2

1

2

5

1

1

1

4

3

$\begin{array}{rr}5 & 42 \\ - & 7\end{array}$

$\begin{array}{ll}- & 2\end{array}$

appliqued fillets 
Table 5. Selected decorative elements on decorated sherds from utility ware vessels at 41SB34, cont.

\begin{tabular}{|c|c|c|c|}
\hline $\begin{array}{l}\text { Decorative method/ } \\
\text { Decorative element }\end{array}$ & Grog & Bone & $\mathrm{N}$ \\
\hline \multicolumn{4}{|l|}{ Incised-Punctated } \\
\hline $\begin{array}{l}\text { curvilinear incised lines and rows of } \\
\text { tool punctates }\end{array}$ & 1 & - & 1 \\
\hline $\begin{array}{l}\text { diagonal lines, } \mathrm{R}-\mathrm{L} \text {, and tool punctated } \\
\text { row at rim-body juncture }\end{array}$ & 1 & - & 1 \\
\hline $\begin{array}{l}\text { horizontal line above rows of circular } \\
\text { punctates }\end{array}$ & 1 & - & 1 \\
\hline $\begin{array}{l}\text { horizontal and curvilinear lines and } \\
\text { curvilinear zone filled with tool } \\
\text { punctates }\end{array}$ & 1 & - & 1 \\
\hline $\begin{array}{l}\text { horizontal and diagonal lines and } \\
\text { triangular zone filled with tool } \\
\text { punctates }\end{array}$ & 1 & - & 1 \\
\hline $\begin{array}{l}\text { incised panel filled with rows of tool } \\
\text { punctates }\end{array}$ & 1 & - & 1 \\
\hline $\begin{array}{l}\text { incised slanting scroll and triangular } \\
\text { tool punctated zones/scroll fill zones }\end{array}$ & 1 & - & 1 \\
\hline incised triangle filled with tool punctates & 1 & 1 & 2 \\
\hline parallel lines and row of tool punctates & - & 1 & 1 \\
\hline $\begin{array}{l}\text { parallel lines and adjacent zone of tool } \\
\text { punctates }\end{array}$ & - & 1 & 1 \\
\hline $\begin{array}{l}\text { straight line and adjacent zone of tool } \\
\text { punctates }\end{array}$ & 4 & - & 4 \\
\hline $\begin{array}{l}\text { vertical tool punctated rows and panels } \\
\text { filled with diagonal opposed lines }\end{array}$ & 1 & - & 1 \\
\hline vertical panel filled with tool punctated row & 1 & - & 1 \\
\hline \multicolumn{4}{|l|}{ Incised-Stamped } \\
\hline $\begin{array}{l}\text { horizontal incised lines and horizontal } \\
\text { stamped row }\end{array}$ & 1 & - & 1 \\
\hline $\begin{array}{l}\text { horizontal incised lines with stamped } \\
\text { row between, and diagonal incised } \\
\text { lines, R-L }\end{array}$ & 1 & - & 1 \\
\hline $\begin{array}{l}\text { triangular incised zone filled with } \\
\text { dentate stamped rows }\end{array}$ & 2 & - & 2 \\
\hline Lip Notched & - & 1 & 1 \\
\hline \multicolumn{3}{|l|}{ Pinched } & 1 \\
\hline \multicolumn{4}{|l|}{ Punctated } \\
\hline small circular punctated rows & 2 & - & 2 \\
\hline circular punctated rows & 1 & - & 1 \\
\hline
\end{tabular}


Table 5. Selected decorative elements on decorated sherds from utility ware vessels at 41SB34, cont.

Decorative method/

Decorative element

Grog Bone

$\mathrm{N}$

tool punctated rows

single tool punctate

1

$-$

1

$-\quad 1$

Ridged-Brushed

parallel ridges and parallel brushed-

1

$\begin{array}{ll}- & 1\end{array}$

incised lines between ridging

Totals

149

17

166

L-R=left-right; incised line begins at the left at the rim and ends at the right at the bottom of the rim; R-L=right to left; incised line begins at the right at the rim and ends at the left at the bottom of the rim

The appliqued sherds have straight or parallel ridges or fillets, likely designed to divide the body of a jar into vertical panels. In these cases, the panels were left plain, but there are other sherds from Pease BrushedIncised jars that have brushing marks filling the panels (see Table 5). The brushed sherds in the utility ware assemblage have horizontal and diagonal brushing marks on jar rims, while vessel bodies have opposed, overlapping, or parallel (likely vertical in orientation) brushing marks. The brushed-incised, brushed-appliqued, brushed-incised-punctated (Figure 8e), and brushed-punctated sherds (also from Pease Brushed-Incised vessels) reflect the variety of decorative elements featuring brushing that occur on vessel bodies.

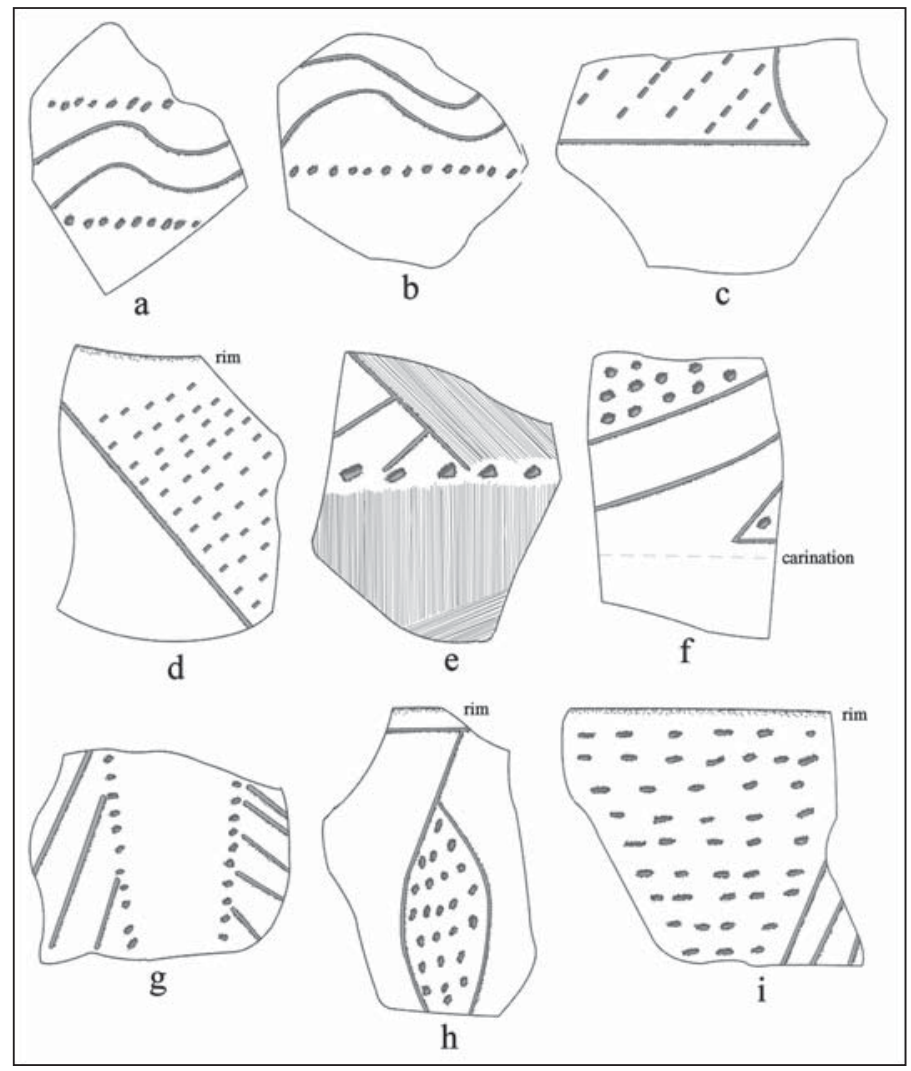

Figure 8. Selected decorative elements in utility ware sherds from 41SB34: a-b, f-i, incised-punctated; c-d, incised-stamped; e, brushed-incised-punctated. 
The vessels with incised decorative elements from 41SB34 have sets of horizontal, diagonal, diagonal opposed (Figure 9a), horizontal-diagonal, and vertical incised lines on the rim (this latter rim may be from a Karnack Brushed-Incised vessel with a plain but short rim and vertical incised lines on the vessel body), as well as a lower rim sherd with an incised slanting scroll and cross-hatched scroll fill zones (Figure 9b). Several body sherds are from Pease Brushed-Incised jars with incised panels filled with diagonal and diagonal opposed incised lines (Figure 9c-d). So to are four incised-appliqued sherds from grog-tempered vessels (see Table 5).

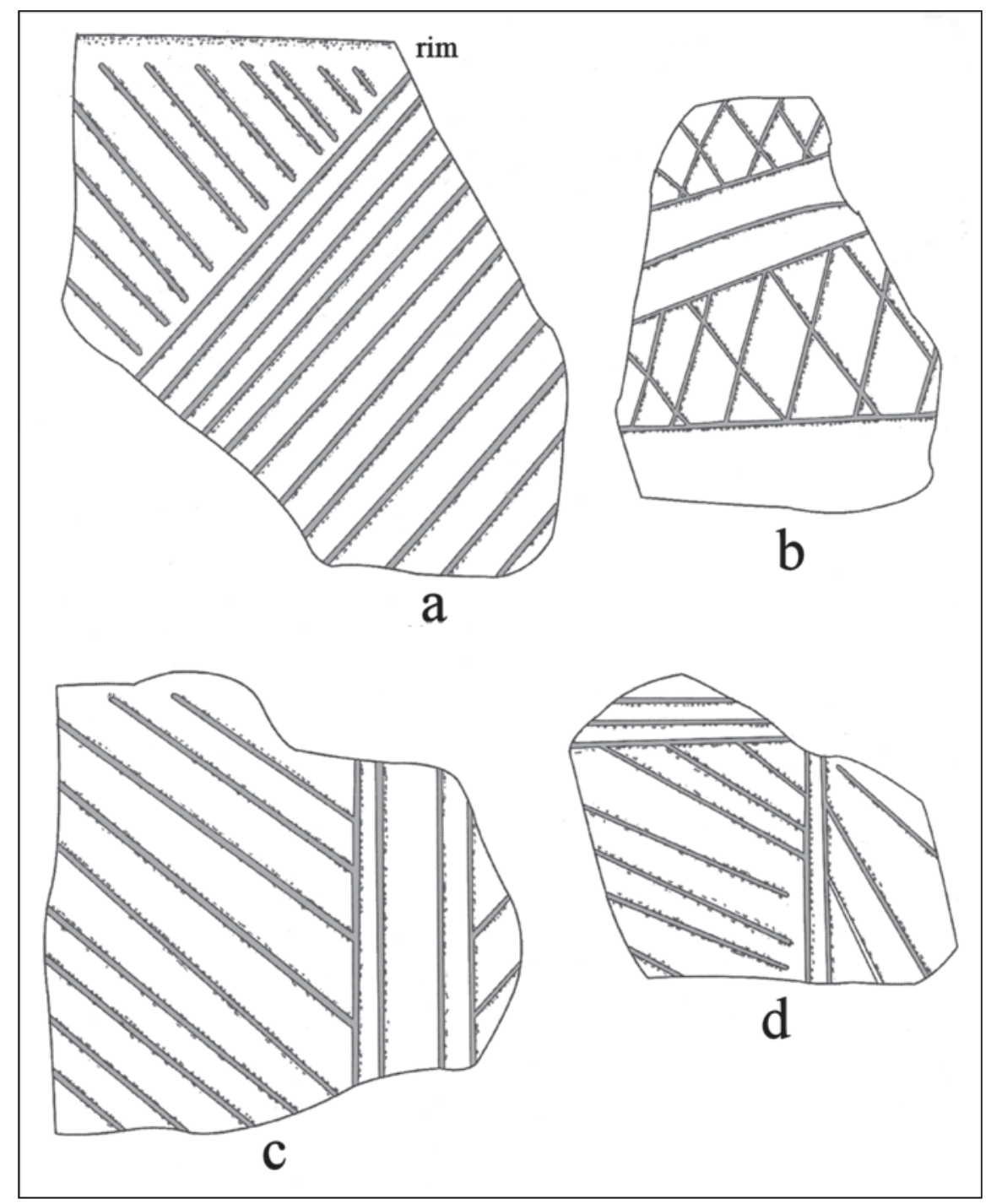

Figure 9. Selected decorative elements in incised rim and body sherds from $41 \mathrm{SB} 34$.

The most distinctive of the incised-punctated rim and body sherds from the site have meandering incised scrolls between single upper and lower rows of small triangular tool punctations (see Figure 8a-b). Others have incised triangles formed by diagonal incised lines, as these triangles are filled with rows of tool punctations (see Figure 8i). One rim has horizontal and curvilinear incised lines with a large pendant semi-circle filled with punctates (see Figure 8h), while another has an incised slanted scroll element with upper and lower scroll fill zones with rows of circular punctations (see Figure 8f). Other rim and body sherds from Pease Brushed-Incised vessels have vertical panels created either with vertical incised lines or vertical rows of punctates, and those panels are filled with vertical punctated rows or diagonal opposed incised lines (see Figure 8g). 
There are four incised-stamped rim and body sherds in the 41SB34 utility ware sherd collection. One rim has a row of linear stamping marks between two horizontal incised lines, while another rim, likely from a Cowhide Stamped jar, has a large triangular-shaped incised area filled with rows of dentate stamps (see Figure 8d). A body sherd has a similar triangular-shaped incised area with diagonal rows of dentate stamping (see Figure 8c), while another body sherd has a row of stamping between two parallel incised lines as well as a set of diagonal opposed incised lines.

The other utility ware sherds from the site include one lip notched rim sherd, a grog-tempered Killough Pinched sherd, several sherds with either rows of circular or tool punctates, and a $15^{\text {th }}$ century A.D. Belcher Ridged, var. Byram Ferry body sherd with brushing marks between parallel ridged elements (see Table 5).

The nine fine ware sherds from 41SB34 include sherds from vessels with either engraved or trailed decorative elements (Table 6). These fine ware sherds only account for 5.1 percent of the decorated sherd sample from the site. The trailed sherds are likely from Keno Trailed bowls (Figure 10a). The engraved sherds feature diagonal lines, hatched triangles, and hatched and cross-hatched zones, as well as a bonetempered rim sherd with horizontal and diagonal lines on the rim panel as well as a diagonal zone filled with hatched lines (Figure 10b).

Table 6. Selected decorative elements on decorated sherds from fine ware vessels at 41SB34.

Decorative method/

Decorative element

Grog Bone N

Engraved

diagonal lines, L-R

hatched triangle

horizontal line and cross-hatched zone

horizontal and diagonal lines, L-R, and

diagonal hatched zone

horizontal, diagonal, and curvilinear lines $\quad 1$

opposed engraved lines

$\begin{array}{lll}- & 1 & 1 \\ 1 & - & 1 \\ 1 & - & 1 \\ - & 1 & 1 \\ 1 & & \\ 1 & - & 1 \\ & - & 1\end{array}$

Trailed

curvilinear trailed lines $\quad 2 \quad-\quad-2$

straight trailed line $\quad 1 \quad-\quad-1$

$\begin{array}{llll}\text { Totals } & 7 & 2 & 9\end{array}$

$\mathrm{L}-\mathrm{R}=$ left-right; engraved line begins at the left at the rim and ends at the right at the bottom of the rim

\section{HOUSEN BAYOU SITES}

The Housen Bayou Caddo sites are the southern cluster of sites discussed in this article (see Figure 1). All three sites are on sandy rises or knolls in the floodplain of Housen Bayou or one of its tributaries, and range from ca. 0.5-2.0 acres.

\section{$41 \mathrm{SB38}$}

When a road had been graded across the sandy rise in the floodplain of Housen Creek, quantities of bones, pottery sherds, and projectile points had been uncovered; some of the bones appeared to be human 


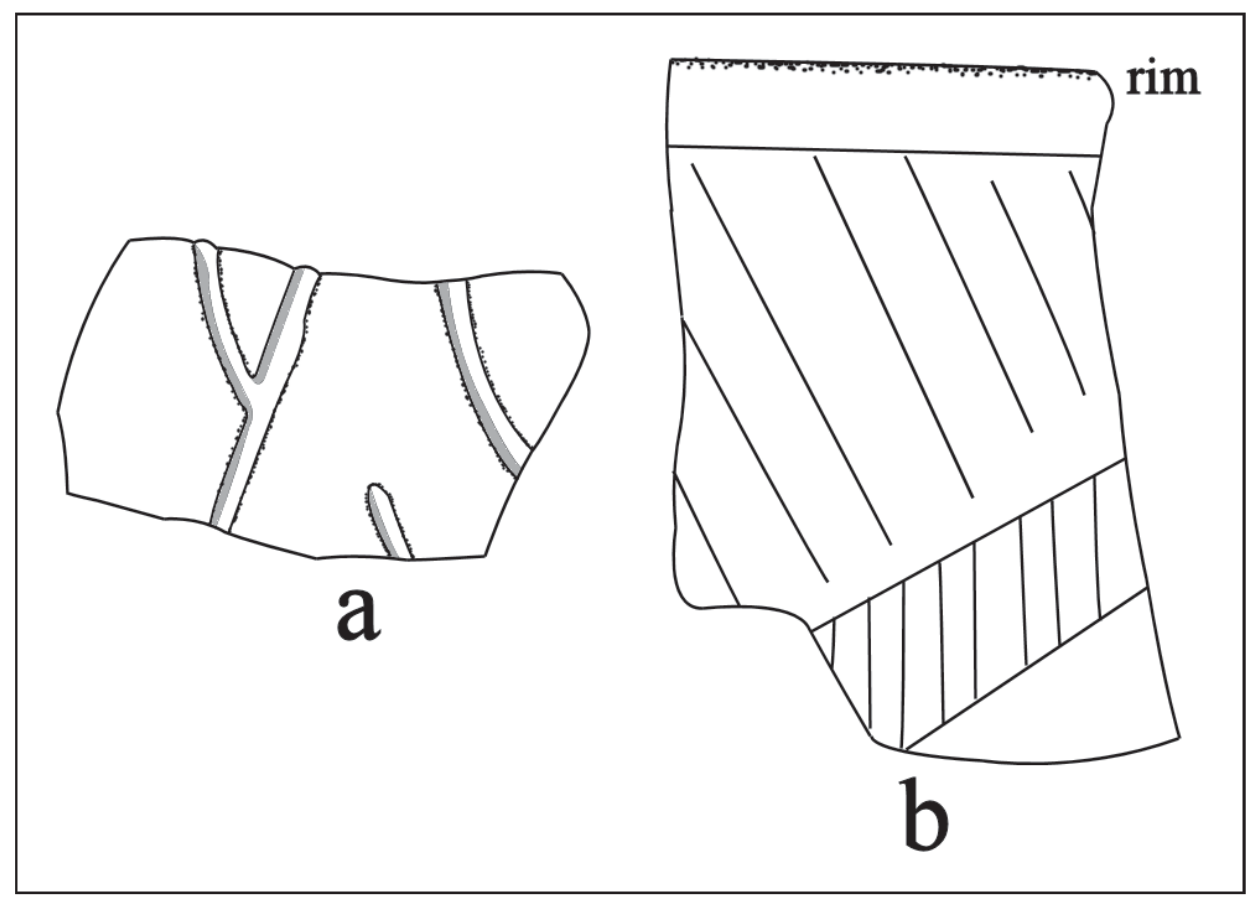

Figure 10. Selected decorative elements in fine ware sherds from 41SB34: a, trailed body sherd; $b$, engraved rim sherd.

(Arnold 1940). When the field adjacent to the road was plowed, "quantities of broken pottery vessels were exposed" (Arnold 1940).

In addition to an Alba arrow point made from a local brown chert, Arnold collected 263 Caddo ceramic sherds from 41SB38. About 98 percent of the sherds are from grog-tempered vessels, and the remaining 2 percent are from bone-tempered vessels.

A total of 125 sherds from the site are decorated, including 118 sherds from utility ware vessels (Table 7). About 63 percent of the utility ware sherds are from vessels with incised decorative elements; 18 percent are from vessels with punctated elements, and 15 percent of the utility ware sherds have incised-punctated decorations. Only 3.4 percent of the utility ware sherds have brushing marks, and 0.8 percent have brushedappliqued decorative elements.

Table 7. Selected decorative elements on decorated sherds from utility ware vessels at 41SB38.

Decorative method/

Decorative element

Grog

Bone

$\mathrm{N}$

\section{Brushed}

parallel brushing marks

\section{Brushed-Appliqued}

parallel brushed and parallel appliqued fillets

\section{Incised}


Table 7. Selected decorative elements on decorated sherds from utility ware vessels at 41SB38, cont.

\begin{tabular}{|c|c|c|c|}
\hline $\begin{array}{l}\text { Decorative method/ } \\
\text { Decorative element }\end{array}$ & Grog & Bone & $\mathrm{N}$ \\
\hline curvilinear line & 1 & - & 1 \\
\hline diagonal lines, R-L & 2 & - & 2 \\
\hline diagonal lines, L-R & 3 & - & 3 \\
\hline diagonal opposed lines & 11 & - & 11 \\
\hline hatched triangles & 1 & - & 1 \\
\hline horizontal-diagonal lines, R-L & 1 & - & 1 \\
\hline opposed lines & 3 & - & 3 \\
\hline parallel lines & 39 & - & 39 \\
\hline straight line & 8 & - & 8 \\
\hline $\begin{array}{l}\text { vertical panel filled with diagonal } \\
\text { opposed lines }\end{array}$ & 3 & - & 3 \\
\hline \multicolumn{4}{|l|}{ Incised-Punctated } \\
\hline $\begin{array}{l}\text { curvilinear incised zones filled with } \\
\text { tool punctates }\end{array}$ & 4 & - & 4 \\
\hline $\begin{array}{l}\text { diagonal opposed lines and diagonal } \\
\text { tool punctated row }\end{array}$ & 1 & - & 1 \\
\hline horizontal lines above tool punctated rows & 1 & - & 1 \\
\hline $\begin{array}{l}\text { horizontal and diagonal lines and } \\
\text { diagonal tool punctated rows }\end{array}$ & 1 & - & 1 \\
\hline $\begin{array}{l}\text { horizontal and diagonal lines and tool } \\
\text { punctated row }\end{array}$ & 1 & - & 1 \\
\hline $\begin{array}{l}\text { incised triangle filled with circular } \\
\text { punctations }\end{array}$ & 1 & - & 1 \\
\hline $\begin{array}{l}\text { incised triangle filled with tool } \\
\text { punctates }\end{array}$ & 1 & - & 1 \\
\hline $\begin{array}{l}\text { parallel lines and adjacent zone of } \\
\text { tool punctates }\end{array}$ & 3 & - & 3 \\
\hline $\begin{array}{l}\text { rectilinear and diagonal lines and } \\
\text { rectilinear row of tool punctates }\end{array}$ & 1 & - & 1 \\
\hline $\begin{array}{l}\text { straight line and adjacent zone of } \\
\text { tool punctates }\end{array}$ & 3 & 1 & 4 \\
\hline \multicolumn{4}{|l|}{ Punctated } \\
\hline small circular punctated rows & 1 & - & 1 \\
\hline fingernail punctated rows & 15 & - & 15 \\
\hline tool punctated rows & 3 & 1 & 4 \\
\hline single tool punctate & 1 & - & 1 \\
\hline Totals & 116 & 2 & 118 \\
\hline
\end{tabular}

$\mathrm{L}-\mathrm{R}=$ left-right; incised line begins at the left at the rim and ends at the right at the bottom of the rim; R-L=right to left; incised line begins at the right at the rim and ends at the left at the bottom of the rim

The one brushed-appliqued body sherd is from a Pease Brushed-Incised vessel with panels formed by vertical appliqued fillets that are filled with brushing marks (Figure 11a). Incised rim sherds have diagonal 
and diagonal opposed lines, and there are several body sherds with vertical and diagonal opposed incised lines that are also from Pease Brushed-Incised vessels (see Suhm and Jelks 1962:Plate 60k).

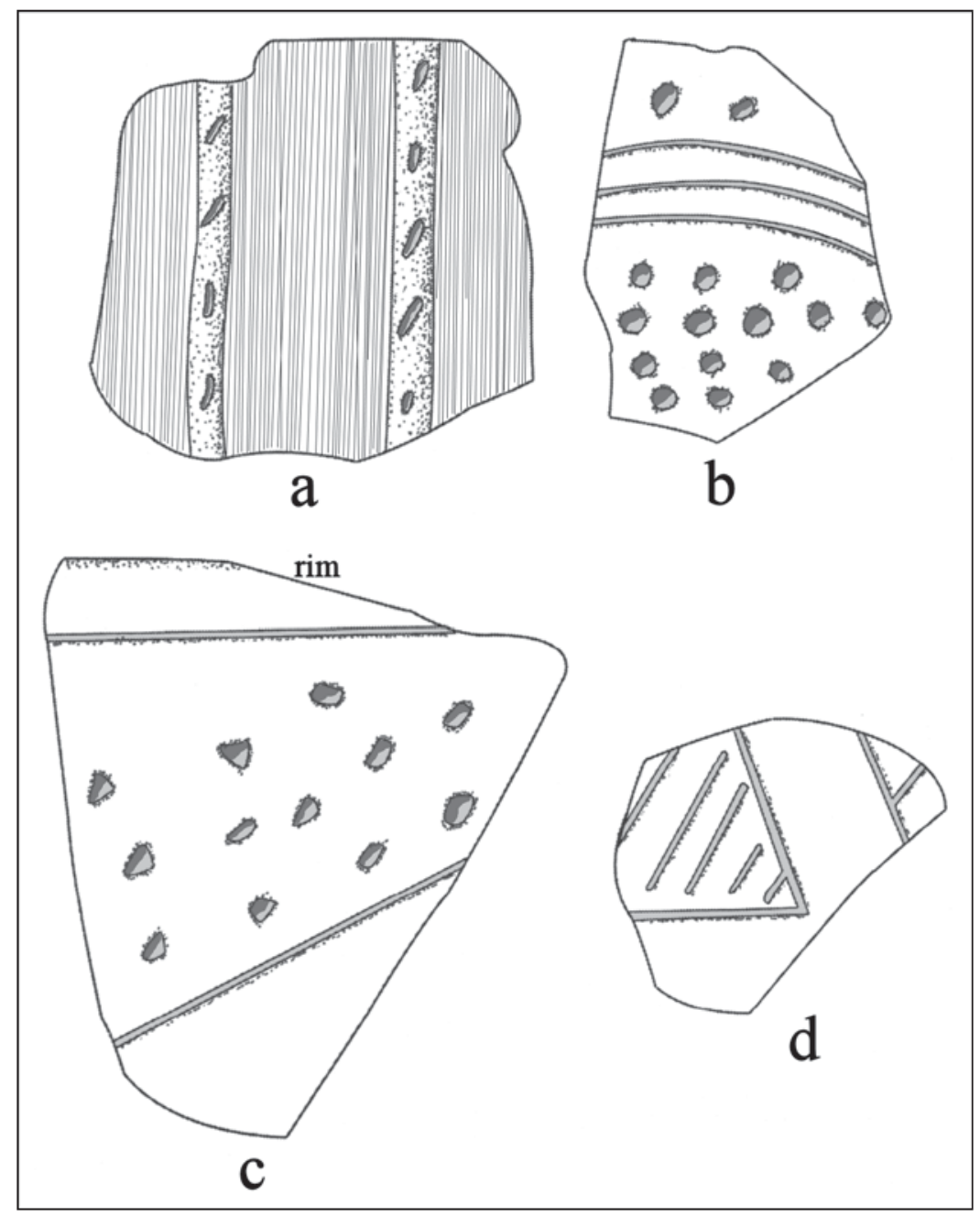

Figure 11. Selected decorative elements in utility ware sherds from 41SB38: a, brushed-appliqued; b-c, incised-punctated; d, incised.

The incised-punctated rim and body sherds have incised triangle elements filled with tool punctations (see Figure 11c), curvilinear incised zones filled with circular punctations (see Figure 11b), rows of tool punctations below a single horizontal incised line below the lip, as well as others with diagonal rows of punctations between diagonal incised zones or in triangular incised zones. Two body sherds have diagonal incised lines that begin in an individual row (straight or rectilinear in orientation) of punctations.

Only seven (5.6 percent of the decorated sherds) of the decorated sherds from 41SB38 are from fine ware vessels. They have parallel lines $(n=1)$, diagonal engraved lines on rim and body sherds $(n=2)$, horizontal lines and a cross-hatched semi-circle $(\mathrm{n}=1)$, vertical panels that are plain or have diagonal hatched lines (Figure 12a), vertical engraved lines $(n=1)$, and horizontal lines and a curvilinear hatched zone $(n=1)$ (Figure 12b).

\section{SB41}

During Arnold's work in 1940, he collected one dart points and 10 ceramic sherds. The dart point, made from a yellowish-gray chert, is a probable Late Archaic period form with an expanding stem, corner notches, small barbs, and a slightly concave base. 


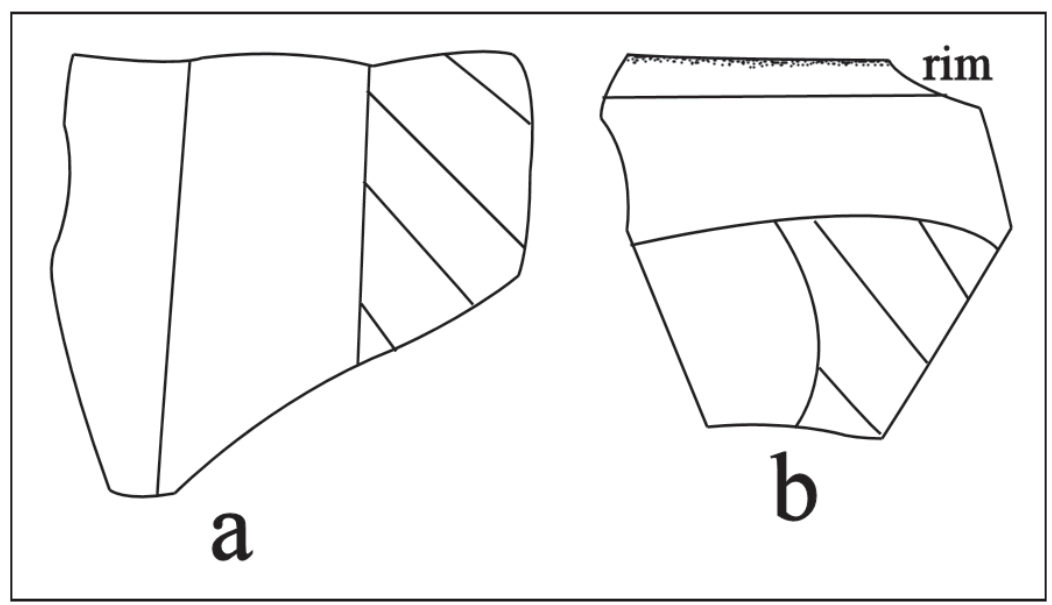

Figure 12. Selected decorative elements in fine ware sherds from 41SB38.

The ceramic sherds include one Woodland period Goose Creek Plain, var. unspecified body sherd and nine ancestral Caddo sherds, both plain $(n=4)$ and decorated $(n=5)$. All of the sherds are from grog-tempered vessels. The decorated sherds have rows of fingernail punctates $(n=1)$; opposed incised lines $(n=1)$; vertical brushing marks $(\mathrm{n}=1)$; a lower rim-body sherds with a row of tool punctations and a horizontal incised line just above the rim-body juncture and diagonal brushing on the vessel body (Figure 13a); and an incisedpunctated rim sherd. This rim has diagonal incised panels that are either plain or filled with rows of tool punctations (Figure 13b).

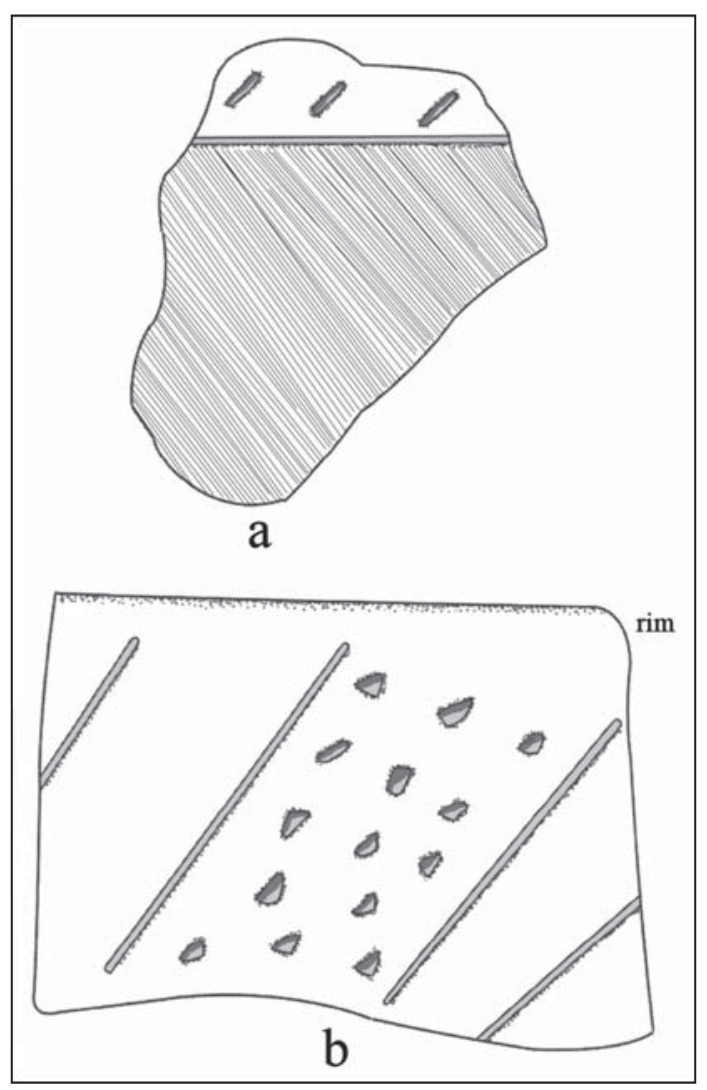

Figure 13. Selected decorative elements in utility ware sherds from 41SB41: a, brushedpunctated-incised; $b$, incised-punctated. 


\section{$41 S B 43$}

The site is on a floodplain rise along Housen Bayou. It probably had midden deposits based on Arnold's (1940) description that mussel shells and bone were noted on the surface. A local collector told Arnold that human burials had been reported from 41SB43.

Arnold collected five arrow points and three dart points from 41SB43. The dart points include two Late Archaic Yarbrough points made from petrified wood and a Gary dart point made from a local brown chert. The arrow points are Alba $(n=1)$, Bassett $(n=1)$, Bonham $(n=2)$, and Colbert $(n=1)$ types. All are made from local cherts: red $(n=2)$, brown $(n=2)$, and yellow $(n=1)$.

Arnold's surface collection from the site also includes 107 ancestral Caddo sherds. About 82 percent of the sherds are from grog-tempered vessels and the remainder are from bone-tempered vessels. A total of 46 sherds have decorations, including 45 sherds from different utility ware vessels and only one sherd (2 percent) from a fine ware vessel. This sherd has a cross-hatched engraved zone.

Fifty percent of the utility ware sherds have incised decorative elements (Table 8). Approximately 35 percent of the utility ware sherds have brushing marks, and 10.9 percent of the sherds have incised-punctated decorative elements. The remaining utility ware sherd has parallel brushed marks and parallel incised lines. The proportion of sherds from 41SB43 with brushed and brushed-incised decorative elements is one of the highest in the set of sites discussed herein from Patroon Bayou, Palo Gaucho Bayou, or Housen Bayou (see below).

Table 8. Selected decorative elements on decorated sherds from utility ware vessels at 41SB43.

Decorative method/

Decorative element

Grog Bone

$\mathrm{N}$

Brushed

parallel brushing marks

14

2

16

Brushed-Incised

parallel brushed-incised

\section{Incised}

diagonal lines

diagonal opposed lines

horizontal lines

horizontal and vertical lines

opposed lines

parallel lines

straight line

vertical lines

1
1
1
1
1
11
1
3

\section{Incised-Punctated}

horizontal and diagonal lines and

triangles filled with tool punctates

incised triangles filled with tool

punctates and diagonal lines

rectilinear panel filled with tool punctates

Totals

40

1

3

1

$\begin{array}{lr}1 & 2 \\ - & 1 \\ - & 1 \\ - & 1 \\ - & 1 \\ 2 & 13 \\ - & 1 \\ - & 3\end{array}$

3

1

3

1

45 
The incised rim sherds have horizontal, vertical, diagonal opposed, and horizontal-vertical lines (see Table 8). One body sherd from a carinated bowl has diagonal incised lines. The incised rim and body sherds have either incised triangle elements filled with tool punctations (Figure 14a, c) or have a rectilinear incised panel filled with tool punctations (Figure 14b).

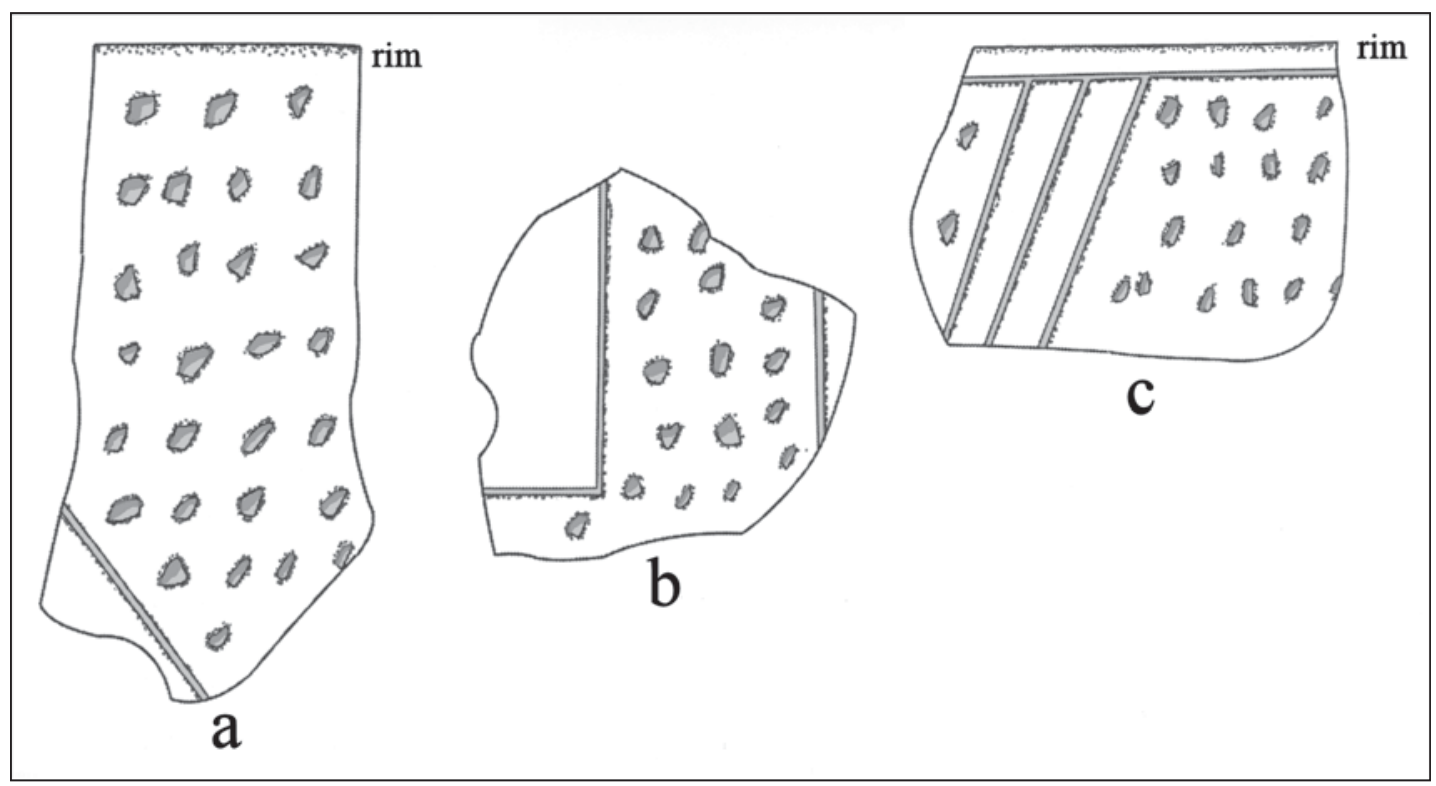

Figure 14. Selected decorative elements in incised-punctated rim and body sherds from 41SB43: a, c, rim sherds; b, body sherd.

\section{SUMMARY AND CONCLUSIONS}

The ancestral Caddo sites on Patroon, Palo Gaucho, and Housen bayous in Sabine County, Texas, discussed in this article, are poorly known habitation sites, as is the Toledo Bend Reservoir area of East Texas and Northwest Louisiana in general. Each of the sites was recorded by G. E. Arnold in 1940 as part of a WPA-sponsored survey of archaeological sites in East Texas, and Arnold obtained substantial surface collections of artifacts (primarily ceramic sherds) from most of the sites. In fact, more than 810 decorated sherds from utility ware and fine ware vessels have been reanalyzed as part of the Caddo documentation research summarized in this article.

Although there are indications from a few of the sites that they were used as early as the Middle Archaic period and as late as the middle part of the Woodland period, each of the sites appears to have been most intensively settled by Caddo peoples, generally after ca. A.D. 1000 to perhaps as late as the early part of the 16th century for sites in the Palo Gaucho Bayou. The period from ca. A.D. 1400-1500 may represent the peak period of Caddo settlement in these three eastward-flowing tributaries of the Sabine River in the East Texas Pineywoods.

Sherds from brushed utility ware vessels, particularly jars, are a distinctive characteristic of both Middle, Late, and Historic Caddo sites in much of East Texas. It also appears to be the case that the relative proportions of brushed utility wares increase through time in those areas where brushed vessels were made and used, such that sherds with brushing marks may comprise as much as 90 percent of all the decorated sherds in some post-A.D. 1400 East Texas ceramic assemblages.

In East Texas Caddo ceramic sherd assemblages, only a few ca. A.D. 1200-1430 sites have high proportions of brushed sherds; these occur in the mid-Sabine and Big Cypress Creek drainage basins. Late Caddo ceramic assemblages in East Texas with high proportions of brushed sherds occur in the upper and 
mid-Neches (Frankston phase sites), Angelina, middle Sabine and Big Cypress (Titus phase sites), and sites (of unknown cultural taxonomy) on tributaries of the Sabine River west of the Toledo Bend Reservoir area, including some of the sites in the Patroon Bayou, Palo Gaucho Bayou, and Housen Bayou.

Differences in the relative proportions of brushed sherds in the decorated sherd assemblages from the sites in the three bayous can consequently be employed as a temporal proxy for estimating the temporal order and likely age of the different site ceramic assemblages (Table 9). Also useful in this regard is the considerable proportion of ridged sherds in Caddo sites at Toledo Bend Reservoir (4-15 percent of the decorated sherd assemblages at the Salt Lick, Goode, and Bison, Area B sites), and in the Burnitt site (16SA204) (35 percent) in the uplands in the Sabine River basin in western Louisiana, that apparently were occupied after ca. A.D. 1500 (Kelley 2006:Table 6-3), and the virtual absence of ridged pottery in the Patroon. Palo Gaucho, and Housen Bayou sites. These differences strongly suggest that the sites discussed in this article were occupied up to, and almost exclusively prior to,A.D. 1500 and likely were abandoned around this time if not before (in the case of 41SB28 and 41SB38).

Table 9. Proposed temporal ordering of ceramic assemblages in the Patroon, Palo Gaucho, and Housen bayous in Sabine County, Texas.

\begin{tabular}{|c|c|c|c|c|c|c|c|}
\hline \multirow[b]{2}{*}{$\begin{array}{l}\text { Ceramic } \\
\text { Attributes }\end{array}$} & \multicolumn{5}{|c|}{ Youngest Sites } & \multicolumn{2}{|c|}{ Oldest Sites } \\
\hline & SB29 & SB43 & $\begin{array}{l}\mathrm{PB}^{*} \\
\text { sites }\end{array}$ & SB34 & SB23 & SB38 & SB28 \\
\hline Brushing & $44.0+$ & 37.0 & 28.2 & 25.1 & 23.5 & 4.2 & 0.7 \\
\hline Incised & 44.0 & 50.0 & 41.0 & 49.1 & 38.2 & 62.7 & 64.2 \\
\hline Incised-Punctated & 7.8 & 10.9 & 15.4 & 9.2 & 5.9 & 15.3 & 21.6 \\
\hline Punctated & 2.7 & - & 5.1 & 2.9 & 29.4 & 17.8 & 12.8 \\
\hline Engraved & 7.0 & 2.2 & 10.3 & 3.4 & - & - & 0.7 \\
\hline Appliqued & - & - & - & $* *$ & - & - & - \\
\hline Ridged & $* *$ & - & - & $* *$ & $* *$ & - & - \\
\hline Incised-Appliqued & $* *$ & - & - & $* *$ & - & - & - \\
\hline Incised-Stamped & $* *$ & - & - & $* *$ & - & - & - \\
\hline Pinched & $* *$ & - & - & $* *$ & - & - & - \\
\hline Lip Notched & - & - & - & $* *$ & - & - & - \\
\hline Trailed & - & - & - & $* *$ & - & - & - \\
\hline$\%$ Grog temper & 56.9 & 82.2 & 83.7 & 89.2 & 59.0 & 97.6 & 90.6 \\
\hline$\%$ Bone temper & 43.1 & 17.8 & 16.3 & 10.8 & 41.0 & 2.4 & 9.4 \\
\hline$\%$ Shell temper & - & - & - & - & $* *$ & - & - \\
\hline $\begin{array}{l}\text { No. of decorated } \\
\text { sherds }\end{array}$ & 274 & 46 & 39 & 175 & 34 & 118 & 148 \\
\hline
\end{tabular}

$* \mathrm{~PB}=$ Patroon Bayou sites as a group, with only 39 decorated sherds

$* *=$ present

$+=$ percentage

The oldest Caddo sites in the Patroon Bayou, Palo Gaucho Bayou, and Housen Bayou areas are 41SB28 and 41SB38 in the Palo Gaucho and Housen bayous, respectively (see Table 9). These are grog-tempered assemblages with very few fine ware sherds, and the decorated sherds are from utility ware vessels dominated by incised, incised-punctated, and punctated decorative elements. Only between 0.7-4.2 percent of the decorated sherds have brushing marks. The very low proportion of brushed sherds, but a corresponding high proportion of vessels with incised, incised-punctated, and punctated decorative elements suggests these 
sites were occupied around and prior to A.D. 1200, when brushed pottery began to be regularly used as a decorative method on utility ware jars in this part of East Texas. Incised sherds have horizontal, horizontaldiagonal, diagonal, and diagonal opposed decorative elements, including sherds from Davis Incised and Dunkin Incised vessels, while the incised-punctated sherds (some likely from Pennington Punctated-Incised vessels) have rows of incised triangles filled with punctations; diagonal incised panels filled with punctations; vertical incised panels filled with punctations or left plain; curvilinear incised zones filled with punctations; horizontal and diagonal incised lines with small incised pendant triangles and large incised triangles filled with circular punctations; and sets of vertical and diagonal opposed incised lines divided by a row of diagonal opposed tool punctations, and below that a triangular zone filled with tool punctations. The sherds from vessels with punctated decorative elements have rows of circular, fingernail, and tool punctated elements on rims and/or bodies of jars.

The youngest group of Caddo sites have considerable amounts of sherds from brushed vessels, between 23.5-44.0 percent of all the decorated sherds in the assemblages (see Table 9). These proportions of brushed sherds are comparable to Late Caddo sites at Toledo Bend Reservoir (see Kelley 2006:Table 6-3). This group of probable Late Caddo sites may also be subdivided into: (a) sites on Palo Gaucho Bayou with high proportions of sherds from bone-tempered vessels (41SB23 and 41SB29), and (b) sites on Patroon Bayou, Housen Bayou, and Palo Gaucho Bayou that have high proportions of sherds from grog-tempered vessels (41SB34, 41SB43, and the sites on Patroon Bayou. In the absence of radiocarbon dates from any of the sites, it is suggested that these sites on Patroon Bayou, Palo Gaucho Bayou, and Housen Bayou were occupied between ca. A.D. 1400-1500. There is no currently defined cultural taxon (i.e., phase) in the East Texas archaeological literature that these sites can be assigned to, although the Angelina focus/phase had been proposed by Jelks (1965). Although this may be an appropriate taxon for sites in the lower Angelina and Attoyac stream basins, but the ceramic assemblages there (i.e., Lake Sam Rayburn) are stylistically different than those from Caddo sites along the Sabine River in the Toledo Bend Reservoir area. The rarity of ridged sherds in the Lake Sam Rayburn sites when compared to their frequency in Toledo Bend Reservoir sites (although not from the sites we have discussed that are on western tributaries to the Sabine River) appears to indicate that the ancestral Caddo groups that once occupied these two areas had distinctly different utility ware traditions. Furthermore, stylistically-related Titus phase and Belcher phase engraved fine wares are absent in the Lake Sam Rayburn sites, which is much different from the Toledo Bend Reservoir ceramic assemblages, a trend which may be indicative of differing populations of Caddo peoples.

Other distinctive decorative attributes in the present grouping of Late Caddo sites, particularly the Palo Gaucho sites, is the occurrence of appliqued, ridged (Belcher Ridged, var. Byram Ferry and var. Belcher), incised-appliqued, incised-stamped (cf. Cowhide Stamped), pinched (Killough Pinched), lip notched, and trailed sherds (probably Keno Trailed) (see Table 9). Fine ware sherds are not common in any of these post-A.D. 1400 Caddo sites. The fine ware sherds from 41SB29, possibly the youngest of the sites, have concentric semi-circle, cross-hatched zone, hatched zone and hatched vertical panels, as well as hatched pendant triangle elements, and also a variety of sherds with horizontal and diagonal, curvilinear, and vertical engraved lines. One rim from a probable Ripley Engraved vessel has a horizontal line below the rim and a central circle element; this circle has an inner engraved diamond. Another engraved rim sherd from 41SB29 has a row of excised pendant triangles on a single horizontal engraved line below the vessel lip.

There are also differences in these ceramic assemblages in the use of tempers to manufacture utility ware and fine ware vessels. Only one site, in the Palo Gaucho Bayou basin, has any sherds from shell-tempered vessels (see Table 9). This is not surprising given the rarity of shell temper use in Caddo pottery in this part of the Sabine River basin (Kelley 2006:50). Both grog (crushed sherds) and burned bone were used as temper in the ceramics from each of the sites. However, bone temper is most common in post-A.D. 1400 Caddo sites in Palo Gaucho Bayou, particularly in the youngest site in the temporal sequence: 41SB29 (see Table 9). The oldest sites, in Palo Gaucho and Housen bayous, apparently predating ca. A.D. 1200, have very little bone temper (2.4-9.4 percent) in the ceramic assemblages (see Table 9). Thus, through time, the use of bone temper by Caddo potters in these parts of the mid-Sabine River basin increased by more than 
33-40 percent from sometime prior to A.D. 1200 to after ca. A.D. 1400 in the Palo Gaucho Bayou and 15 percent in the Housen Bayou sites.

\section{ACKNOWLEDGMENTS}

Thanks to Jonathan Jarvis of the Texas Archeological Research Laboratory at The University of Texas at Austin for facilitating access to the records and collections from these Sabine County sites. Lance Trask prepared the figures for this article.

\section{REFERENCES CITED}

Arnold, G. E.

1940 Site forms. On file at the Texas Archeological Research Laboratory, The University of Texas at Austin.

Benham, B. L., H. L. Miller, and J. V Sciscenti

1973 Archaeological Research in the Toledo Bend Reservoir. Archaeology Research Program, Southern Methodist University, Dallas.

Brown, I. W.

1998 Decorated Pottery of the Lower Mississippi Valley: A Sorting Manual. Mississippi Archaeological Association and Mississippi Department of Archives and History, Jackson.

Girard, J. S.

2007 Byram Ferry (16BO17): A Middle to Late Caddo Period Mound Site in the Red River Floodplain, Northwest Louisiana. Caddo Archeology Journal 16:9-25.

Jelks, E. B.

1965 The Archeology of McGee Bend Reservoir, Texas. Ph.D. dissertation, Department of Anthropology, The University of Texas at Austin.

Jensen, H. E.

1968a Coral Snake Mound (X16SA48). Bulletin of the Texas Archeological Society 39:9-44.

1968b Archaeological Investigations in the Toledo Bend Reservoir: 1966-1967. Archaeology Salvage Project, Southern Methodist University, Dallas.

Kelley, D. B.

2006 The Burnitt Site: A Late Caddoan Occupation in the Uplands of the Sabine River Basin of Louisiana. Coastal Environments, Inc., Baton Rouge.

Kelley, D. B., D. G. Hunter, K. M. Roberts, S. L. Scott, and B. S. Haley

2010 The Burnitt Site (16SA204): A Late Caddoan Occupation in the Uplands of the Sabine River Basin. Louisiana Archaeology 31:4-33.

McClurkan, B. B., W. T. Field, and J. N. Woodall

1966 Excavations in Toledo Bend Reservoir, 1964-65. Papers of the Texas Archeological Salvage Project No. 8. Texas Archeological Salvage Project, The University of Texas at Austin.

Robinson, D. G.

1997 Cultural Resource Investigations at the Ducks Unlimited Marsh (DUM) Project, North Toledo Bend Reservoir, Shelby County, Texas. Report 97-3. Cultural Resource Program, Texas Parks and Wildlife Department, Austin. 
Scurlock, J. D.

1964 Archeological Reconnaissance at Toledo Bend Reservoir, 1962-1963 Season. Texas Archeological Salvage Project, The University of Texas at Austin.

Scurlock, J. D. and W. A. Davis

1962 Appraisal of the Archeological Resources of Toledo Bend Reservoir, Panola, Newton, Sabine, and Shelby Counties, Texas; Sabine and DeSoto Parishes, Louisiana. Texas Archeological Salvage Project, The University of Texas at Austin.

Suhm, D. A. and E. B. Jelks (editors)

1962 Handbook of Texas Archeology: Type Descriptions. Special Publication No. 1, Texas Archeological Society, and Bulletin No. 4, Texas Memorial Museum, Austin. Reprinted in 2009, Gustav's Library, Davenport, Iowa.

Woodall, J. N.

1969 Archeological Excavations in the Toledo Bend Reservoir, 1966. Contributions in Anthropology No. 3. Department of Anthropology, Southern Methodist University, Dallas. 